\title{
Review \\ The Inflammatory Profile of Obesity and the Role on Pulmonary Bacterial and Viral Infections
}

\author{
Franziska Hornung ${ }^{1}$, Julia Rogal ${ }^{2,3}$, Peter Loskill ${ }^{2,3}{ }^{(\mathbb{D}}$, Bettina Löffler ${ }^{1}$ and Stefanie Deinhardt-Emmer ${ }^{1,4, *(\mathbb{D})}$ \\ 1 Institute of Medical Microbiology, Jena University Hospital, Am Klinikum 1, D-07747 Jena, Germany; \\ franziska.hornung@med.uni-jena.de (F.H.); bettina.loeffler@med.uni-jena.de (B.L.) \\ 2 Department of Women's Health, Research Institute for Women's Health, Eberhard Karls University, \\ Calwerstrasse 7, 72076 Tübingen, Germany; julia.rogal@igb.fraunhofer.de (J.R.); \\ peter.loskill@uni-tuebingen.de (P.L.) \\ 3 Fraunhofer Institute for Interfacial Engineering and Biotechnology IGB, Nobelstrasse 12, \\ 70569 Stuttgart, Germany \\ 4 Center for Sepsis Control and Care, Jena University Hospital, D-07747 Jena, Germany \\ * Correspondence: Stefanie.deinhardt-emmer@med.uni-jena.de; Tel.: +49-03641-9-393617
}

Citation: Hornung, F.; Rogal, J.;

Loskill, P.; Löffler, B.;

Deinhardt-Emmer, $\mathrm{S}$. The

Inflammatory Profile of Obesity and the Role on Pulmonary Bacterial and Viral Infections. Int. J. Mol. Sci. 2021, 22, 3456. https://doi.org/10.3390/ ijms22073456

Academic Editor: Aurora Daniele

Received: 17 February 2021

Accepted: 23 March 2021

Published: 26 March 2021

Publisher's Note: MDPI stays neutral with regard to jurisdictional claims in published maps and institutional affiliations.

Copyright: (c) 2021 by the authors. Licensee MDPI, Basel, Switzerland. This article is an open access article distributed under the terms and conditions of the Creative Commons Attribution (CC BY) license (https:// creativecommons.org/licenses/by/ $4.0 /)$.

\begin{abstract}
Obesity is a globally increasing health problem, entailing diverse comorbidities such as infectious diseases. An obese weight status has marked effects on lung function that can be attributed to mechanical dysfunctions. Moreover, the alterations of adipocyte-derived signal mediators strongly influence the regulation of inflammation, resulting in chronic low-grade inflammation. Our review summarizes the known effects regarding pulmonary bacterial and viral infections. For this, we discuss model systems that allow mechanistic investigation of the interplay between obesity and lung infections. Overall, obesity gives rise to a higher susceptibility to infectious pathogens, but the pathogenetic process is not clearly defined. Whereas, viral infections often show a more severe course in obese patients, the same patients seem to have a survival benefit during bacterial infections. In particular, we summarize the main mechanical impairments in the pulmonary tract caused by obesity. Moreover, we outline the main secretory changes within the expanded adipose tissue mass, resulting in chronic low-grade inflammation. Finally, we connect these altered host factors to the influence of obesity on the development of lung infection by summarizing observations from clinical and experimental data.
\end{abstract}

Keywords: obesity; lung infection; adipocytokines; bacteria; viruses; obesity paradox

\section{Introduction}

Obesity is becoming a growing health problem worldwide. It is generally defined as a condition of increased adipose tissue mass [1] and can be further specified as an accumulation of body mass beyond physical requirements [2]. The WHO describes obesity and overweight as excessive fat accumulation leading to higher morbidity rates for various health problems [3]. In 1842, Adolphe Quetelet conducted pioneering work in analyzing the differences in the weight status of individuals [4]. The Quetelet dindex is calculated by dividing weight by height squared and is known nowadays as the Body Mass Index (BMI), which is still the most common way of classifying obesity [5]. Using this scale, overweight is defined as a BMI greater than or equal to 25 and obesity as a BMI greater than or equal to 30 [3].

With more than 1.9 billion overweight adults in 2016 and a worldwide tripling of the number of obese persons since 1975 [3], obesity has spread around the world and now affects a considerable part of the human population. This high prevalence represents a huge problem for our health care systems, because "Corpulence is not only a disease itself but the harbinger of others", as Hippocrates already knew more than two millennia ago [6]. Metabolic diseases (e.g., type 2 diabetes mellitus), bone and soft tissue pathologies 
(e.g., osteoarthritis), and cardiovascular diseases (e.g., hypertension) belong to the main comorbidities of obesity. Moreover, obesity also leads to impaired lung function, increased occurrence of asthma, and obstructive sleep apnoea syndrome (OSA) [7]. Since obesity contributes to a wide variety of comorbidities, an excess of adipose tissue mass is expected to lead to a variety of molecular changes in the body. Regarding respiratory infections, an increased sensitivity has been observed, which might be connected to the above-mentioned increased incidence of comorbidities but also by a chronic low-grade inflammatory status.

In the process of infection progression, obese patients have been reported to show benefits or disadvantages compared to normal-weight subjects depending on the type of infection. On the one hand, the "obesity paradox" describes a benefit for the obese, e.g., in sepsis [8]. On the other hand, certain infections take a markedly more severe course in obese patients compared to normal-weight patients, as the current coronavirus disease (COVID-19) pandemic clearly illustrates $[9,10]$. Thus, the "obesity paradox" proposes that obese patients, although presenting numerous comorbidities, show a survival benefit [11].

Here, we summarize the main mechanical impairments in the pulmonary tract caused by obesity and particularly the molecular alterations within adipose tissue that go along with its expansion. Most notably, we outline the main secretory changes within the expanded adipose tissue mass, resulting in the establishment of chronic low-grade inflammation. To mimic obesity in different experimental settings either in vivo or in vitro specialized models are needed to study the underlying mechanisms. Our review additionally focuses on model systems suitable for mechanistic studies of biology and signal transduction in adipose tissue. With this knowledge, we connect the mentioned altered host factors to the influence of obesity on the development of lung infection by summarizing observations from clinical as well as from experimental data. Finally, we discuss the differences between bacterial and viral infections concerning the effect of obesity.

\section{The Mechanic Pulmonary Complications of Obesity}

An increase in adipose tissue and fat deposition throughout the body has a direct impact on the upper airway and pulmonary function. Especially, the deposition of fat in the upper part of the body reduces the airway lumen and impairs the muscles important in maintaining the full respiratory function, resulting in OSA [12].

The combination of severe obesity and hypoventilation is described as ObesityHypoventilation syndrome (OHS) [13]. According to Sharp et al. [14], the chest wall and total respiratory compliance for obese patients range from $92 \%$ to $80 \%$ and for patients with additional OHS from $44 \%$ to $37 \%$ to of normal values. A possible reason for this deficit could be an expanded blood volume and the subsequent closure of corresponding air passages, two parameters influencing lung compliance. Furthermore, the resistances of the airway, chest wall, and respiratory system are elevated in obese individuals, especially in OHS patients, and might be caused by a reduction in lung volume [14]. These changes are also associated with an impaired Work of Breathing (WOB). Simply and severely obese subpatients have a $70 \%$ to $280 \%$ higher WOB than normal and accordingly an extremely increased cost of breathing [15]. The work of breathing is defined as the energy, which is needed to inhale and exhale breathing gas, referred to as work per unit volume. Moreover, simple obese and OHS patients show a decrease in strength and endurance of the inspiratory and expiratory muscles, possibly due to enlargement or overstretching of the diaphragm [16]. The lung volumes of simple obese patients are generally not profoundly altered, except for a reduction in the expiratory reserve volume, potentially caused by the displacement of the diaphragm into the chest. Only very severe types with additional OHS show additional alterations in other lung volumes [7]. This effect is most likely not caused by a simple BMI increase but by a change in fat distribution, e.g., in the chest wall, abdominal wall, or abdomen [7]. Especially eucapnic morbidly obese patients show a difference in the pattern of breathing because their respiratory rate at rest is around $40 \%$ higher than normal [17]. Obese patients, especially those with small lung volume and in a 
supine position, are often hypoxemic, leading to a mismatch of ventilation and perfusion, which influences the gas exchange in the lung [18].

Even though obese individuals have an almost $25 \%$ higher oxygen consumption at rest than normal, young individuals show similar performance during exercise in terms of heart rate and blood pressure [17]. Merely at resting-phases between exercises, higher respiratory rate (RR) and lower tidal ventilation values can be observed [19]. Obesity can cause a number of further medical complications concerning the pulmonary system: For example, the risk of developing aspiration pneumonia is increased in obese patients, mainly caused by a higher volume of gastric fluid, lower $\mathrm{pH}$ in the gastric system, elevated pressure in the abdomen, or gastroesophageal reflux [20]. Obese subjects are at higher risk for postoperative thromboembolic disease [21] and pulmonary embolism [22] resulting in challenging anesthesia in obese patients [23]. Difficulties can, for instance, arise during intubation with atelectasis being a severe side effect in $30 \%$ of obese patients [23]. Furthermore, difficulties in mechanical ventilation and acute postoperative respiratory events can occur [24]. These impairments could represent a physical basis for the increased susceptibility to infections of the pulmonary tract and additional hinder its treatment.

\section{The Inflammatory Activity of Adipose Tissue}

Adipose tissue is classified into two main types, white adipose tissue (WAT) and brown adipose tissue (BAT). WAT is the more predominant form in the human body and plays a major role in energy storage. Thermogenesis is the main function of BAT. It was thought to be rather present in small mammals and human neonates [25]. Nedergaard et al. indeed revealed its presence in adult tissue [26].

Adipocytes are in general the main cell type within adipose tissue. They can be further classified according to their microscopical appearance [27]. A unilocular positioned lipid-vacuole characterizes white adipocytes, the predominant form in the WAT. Brown appearing adipocytes are defined by multilocular lipid-vacuoles and an increased amount of mitochondria, which is connected to their function in heat production in BAT. Both, WAT and BAT, are capable to transdifferentiate between the subtypes in response to the physiological conditions [28]. The intermediate cell forms are called beige adipocytes [29]. White adipocytes are additionally able to transdifferentiate into epithelial, milk-producing cells in the breast of pregnant women. These cells are named after their visual appearance, the pink adipocytes [30].

Besides adipocytes, also pre-adipocytes, endothelial cells, fibroblasts, leukocytes, and bone-marrow-derived macrophages are part of adipose tissue [31]. The number of macrophages positively correlates with body mass, adipocyte size, and expression of pro-inflammatory cytokines [32].

One of the main physiological functions of WAT is the regulation of fat reservoirs in the body via triacylglycerols (TG) stored in adipocytes. The mobilization and storage of TG must be well balanced with and connected to the energy intake and expenditure of the whole body. In this context, the lipolysis, i.e., the metabolization of TG, is also regulated by the autonomic nervous system, in particular adrenergic and cholinergic neurons [33].

In addition to energy storage, adipose tissue has an important endocrine function secreting a number of crucial soluble factors: Specific to adipose tissue are the so-called "adipocytokines" or "adipokines", including, e.g., adiponectin, leptin, resistin, and visfatin [31]; described in more details in the next chapter. Other important produced factors include the cytokines tumor necrosis factor (TNF), interleukin-6 (IL-6), interleukin-1 (IL-1), CC-chemokine ligand 2 (CCL2), plasminogen activator inhibitor type I (PAI-I), and a number of complement factors [34,35]. Most of these factors are known as pro-inflammatory mediators that induce immune cell infiltration and play a major role in the development of infectious diseases.

According to the location of the deposition, adipose tissue can be further classified in subcutaneous adipose tissue (SCAT) and visceral adipose tissue (VAT). The excessive production of fat tissue during weight gain leads to a depletion of storage capacities and 
can result in ectopic lipid accumulation in visceral body cavities, skeletal muscle, or liver tissue [36,37]. This phenomenon can for instance play a major role in the development of insulin resistance [38].

An increase in adipose tissue mass during weight gain can be on a cellular level either orchestrated by an increase in the size of the adipocytes (hypertrophy) or their number (hyperplasia). Besides simple mass expansion, the tissue additionally passes through a process of remodeling characterized by extracellular matrix (ECM) overproduction, increased immune cell infiltration, and higher pro-inflammatory response [39].

Specifically, the crosstalk between adipocytes and macrophages plays an important role in the remodeling [40]. The elevated infiltration leads to the expression of macrophagerelated inflammatory genes [41]. In this context, Sun et al. [39] proposed four different mechanisms as potential key initiator processes of macrophage migration to the adipose tissue: adipocyte death, chemotactic regulation, hypoxia, and fatty acid flux. Thus, the excess of body weight via increased adipose tissue mass results in a state of low-grade chronic inflammation (Figure 1).

lean

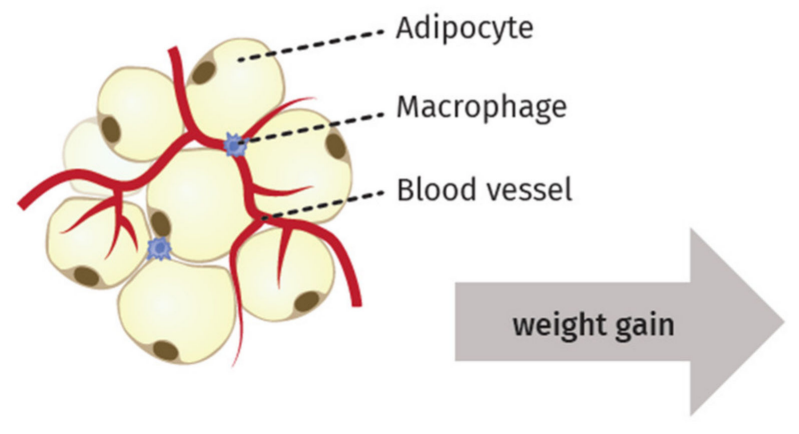

obese
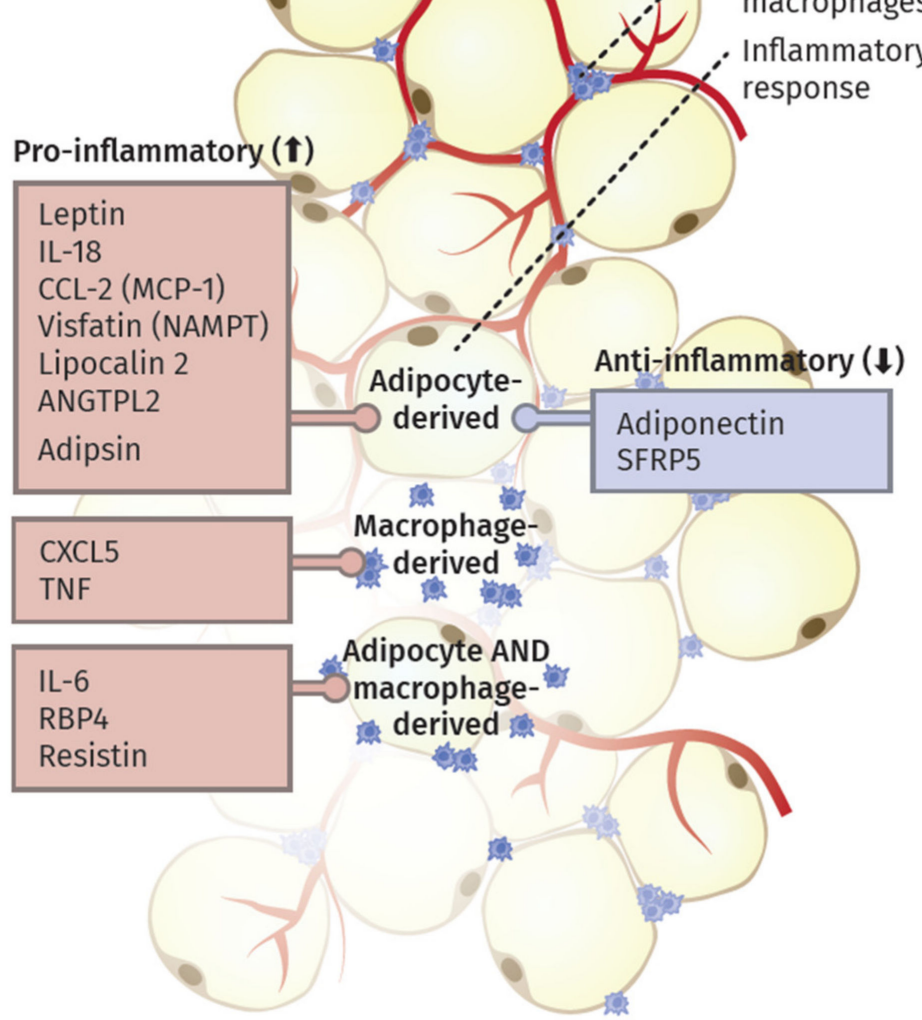

Figure 1. The remodeling process in adipose tissue during weight gain. White adipose tissue is primarily composed of adipocytes, macrophages and blood vessels. To cope with an elevated amount of triacylglycerols (TG) during weight gain, adipocytes increase in size (hyperplasia) and number (hypertrophy). This can further result in the apoptosis of adipocytes, chemotactic regulations, hypoxia and free fatty acids. All four mechanisms are discussed to foster the heightened migration of macrophages into the adipose tissue. Moreover, the secretions of different adipocytokines, produced in adipocytes, macrophages or in both cell type, are influenced. In general, anti-inflammatory secretory products are downregulated, whereas the secretion of pro-inflammatory adipocytokines is elevated. These developments provide a low-grad proinflammatory environment, which arises from the increased and remodeled adipose tissue in obese subjects. 
Saltiel et al. [42] suggested the occurrence of a "phenotypic switch" during polarization of macrophages from an anti-inflammatory M2 type to the M1 form. In lean individuals, the polarized M2 type seems to encourage the normal function of adipocytes by promoting repair of tissue and angiogenesis, i.e., the sprouting of new vessels to ensure an appropriate oxygen supply. In obese individuals, the M1 type is fostering an inflammatory milieu in the adipose tissue by secreting factors like TNF- $\alpha$, inducible nitric oxide synthase (iNOS), C-C chemokine receptor type 2 (CCR2) or monocyte chemotactic protein 1 (MCP1). Sun et al. [40] proposed that this switch in polarized macrophages defines the fate of adipocyte function and the overall inflammatory profile of the tissue. They also discriminated between healthy and pathological adipose tissue expansion. In the former, an increase in mass happens mainly via a growing number of small adipocytes, recruitment of other stromal cells, maintenance of oxygen supply, and only minimal induction of ECM production and inflammation. In contrast, pathological expansion is defined as a rapid increase in the size of existing adipocytes with hypoxia due to decreased blood vessel formation, massive ECM deposition, and a higher number of macrophages, especially the pro-inflammatory M1 type, leading to a state of chronic inflammation.

In summary, this chapter highlights the complex composition and inflammatory potential of adipose tissue in obese patients. Hence, it is assumed that the calculation of a person's BMI by using solely two parameters might lead to misclassifications and excludes important parameters such as percentage body fat (PBF) or rather molecular biomarkers. With regard to the investigations of predispositions for various diseases, it should be considered to include more parameters. In this context, DeLorenzo et al. [43] summarized four obese phenotypes: (1) normal weight obese, (2) metabolically obese normal weight; (3) metabolically healthy obese and (4) metabolically unhealthy obese. Here additional factors concerning body fat composition and distribution (such as fat mass, glucose-levels or CRP-levels) are taken into account. This would also specify the analysis of the impact of obesity on infectious diseases.

\section{Adipocytokines Produced by Adipose Tissue}

Since the discovery of leptin in 1994, adipose tissue is also known as an endocrine organ, besides its function contributing to energy storage [44]. It can express and secrete a range of proteins, which are termed adipocytokines or adipokines, because of their main but not exclusive production in this specialized type of tissue [31]. In the following section, the main adipokines and their function in inflammatory processes are described. Additionally, we highlight their origin and detected alterations during weight gain (Figure 1).

\subsection{Pro-Inflammatory Molecules of the Adipose Tissue}

Leptin is the best-characterized adipokine, mainly produced by adipocytes. It was discovered in the 1960s with the help of parabiotic experiments with two mouse strains, the $o b / o b$ (obese) and $d b / d b$ (diabetes) mutant. This procedure aims at the surgical joining of two mice, leading to the coupling of their blood circulation and enabling the analysis of different physiological or hormonal processes [45]. Both of the investigated mutants result in an obese phenotype. By conjoining individuals of those strains with each other or with lean mice, respectively, different weight changes were observed. Remarkably, the $d b / d b$ mouse overexpressed a factor but was not able to respond to it with weight loss. In fact, the $o b / o b$ mouse could not produce this factor but reacted to it by losing weight while connected with the $d b / d b$ mutant or the respective wildtype [46]. 40 years later, this factor and product of the $o b$ gene that seemed to orchestrate the bodyweight of the two mutant strains was named leptin (Greek: leptos = thin) [44]. The gene product of $d b$ was termed ObR, the corresponding receptor [47].

An overview of the main downstream branches of leptin are schematically displayed in Figure 2. Leptin is a $16 \mathrm{kDa}$ polypeptide that shows structural similarities to the longchain cytokines IL-6, IL-12, or G-CSF, all known to contribute to inflammation [48]. The leptin-receptor is a type I cytokine receptor type and exists as six alternatively spliced 
isoforms with varying intracellular, cytoplasmic parts [49]. One long (ObRb), four short (ObRa, ObRc, ObRd, and ObRf) and one soluble form (ObRe) exist. Only the long isoform possesses the entire intracellular domain, with the conserved tyrosine residues (Y985, Y1077, Y118) [50]. Besides the expression in the hypothalamic region of the brain, where the main function of appetite regulation is orchestrated via leptin signaling, other tissues also express leptin receptor isoforms, including the heart, placenta, liver, muscle, kidney, pancreas, spleen thymus, prostate, testes, ovary, small intestine, and colon [51]. Remarkably, Tsuchiya et al. [52] revealed that the human leptin receptor also occurs in lung tissue.

Leptin exerts its function in the hypothalamus via the activation of anorexigenic POMC (Proopiomelanocortin) neurons and orexigenic NPY (Neuropeptide Y)/AgRP (Agoutirelated Protein) neurons [53]. The most prominent downstream signaling component of the leptin receptor is the JAK (Janus kinase)/STAT (signal transducer and activator of transcription) pathway [54]. An important downstream gene is SOCS3 (Suppressor of cytokine signaling 3), which itself acts as a potent negative regulator of the leptin signaling, by inhibiting JAK2 [55]. Another signaling branch activated via leptin is the MAPK (Mitogen-activated protein kinase) pathway. Here, the SH2 domain of the phosphatase SH2containing protein tyrosine phosphatase 2 (SHP2) binds to pY985, becomes phosphorylated by JAKs, which finally activates MAPK extracellular signal-related kinase (ERK1/2) via recruitment of growth factor receptor-bound protein 2 (Grb2) [56]. Leptin also activates Akt by triggering the phosphatidylinositol 3 kinase (PI3K) signaling pathway. Akt inhibits forkhead box O1 (Foxo1), the mediator of the previously mentioned function of leptin in the hypothalamus [57]. Furthermore, downstream of Akt is the Ser/Thr kinase mTOR (mammalian target of rapamycin), a mammalian sensor for the availability of nutrients and stimulator of cell growth, protein biosynthesis, and proliferation [58]. Leptin stimulates the AMPK (adenosine monophosphate-activated protein kinase) pathway, but the outcome differs between the tissues. While activated in hepatocytes and muscle [59], AMPK is inhibited in the hypothalamus, resulting in inhibition of food intake [60].

The observations gained from the parabiosis experiments reflect one main function of leptin: the regulation of food intake and energy expenditure via the leptin-hypothalamus axis. In the hypothalamus, leptin activates anorexigenic neurons, thereby decreasing food intake; at the same time, it leads to the inactivation of orexigenic neurons that stimulate appetite and intake [53]. Counterintuitive to this role in food intake regulation, the level of leptin in the systemic circulation of obese persons is elevated and positively correlated with adipose mass. This hyperleptinemia is a consequence of developing leptin resistance [61] Several potential explanations for this effect are discussed. On the one hand, the action of a negative feedback loop orchestrated by SOCS3, activated by leptin could serve as a potential link to the leptin resistance. The protein tyrosine phosphatase $1 \mathrm{~B}$ (PTP1B) is capable to inhibit the leptin receptor activity by dephosphoryltion of JAK2 [62]. On the other hand, disturbances in the hypothalamic neuronal wiring, impairments in the transport of leptin to the brain, the ObR trafficking, ER stress, or inflammation itself are discussed as potential key events for the development of leptin resistance [49].

Besides its regulatory function in the hypothalamus, leptin itself is defined as a proinflammatory adipokine and plays a major role in innate and adaptive immunity [63]. In monocytes, it induces increased production of TNF, IL-6, and ROS as well as cell proliferation [64], thereby stabilizing their activation, phagocytotic activity, and cytokine production [25]. In turn, leptin expression is also elevated by pro-inflammatory cytokines such as TNF and IL-1, indicating a bidirectional interaction between leptin and inflammation [65]. In addition to its interaction with cytokine pathways, leptin stimulates the production of CC-chemokine ligands (CCL3, CCL4, and CCL5) in macrophages [64]. Leptin can also trigger the chemotaxis and ROS production of neutrophils as well as the differentiation, proliferation, activation, and cytotoxicity of natural killer (NK)-cells [66]. Moreover, it inhibits apoptosis and improves the activation and proliferation of T lymphocytes [67]. It also promotes the Th1 phenotype of lymphocytes and the production of IL-2 and IFN $\gamma$, while inhibiting the Th2 type and the expression of IL-4 [68]. 


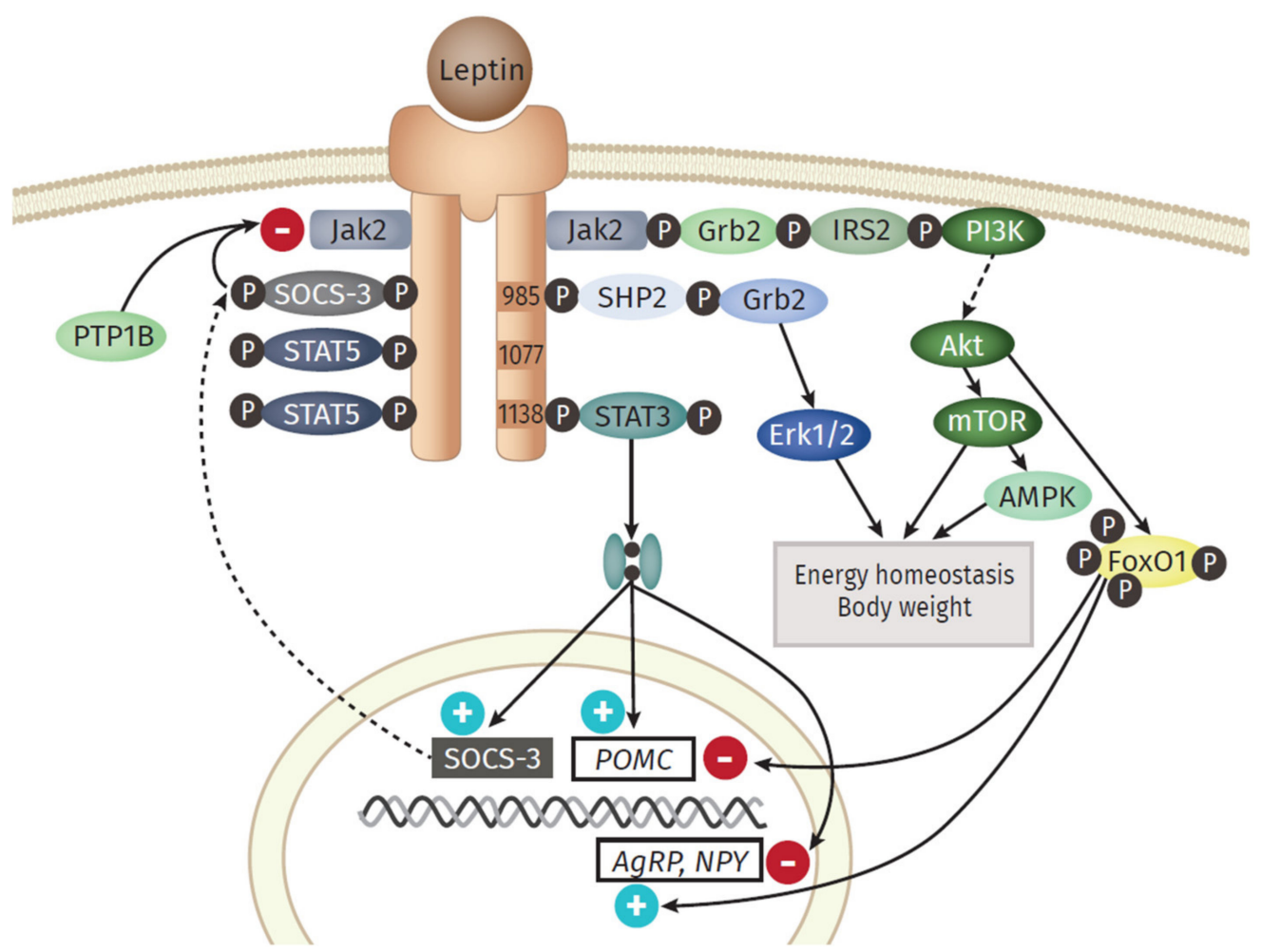

Figure 2. Overview of the leptin signaling pathway. The long isoform of the leptin receptor (ObRb) possesses the whole intracellular domain, with the conserved tyrosine residues (Y985, Y1077, Y118). The central function of leptin in the hypothalamus is regulated via the activation of anorexigenic neurons and orexigenic Neuropeptide Y (NPY)/Agouti-related Protein (AgRP) neurons. The most prominent downstream signaling component of the leptin receptor is the Janus kinase (JAK)/signal transducer and activator of transcription (STAT) pathway. After binding of leptin, subsequent dimerization of the receptor and the following activation of JAK2 occurs, followed by the recruitment of the Src homology 2 (SH2) domain of STAT3 to the conserved phosphorylated tyrosine Y705 residue. Hereinafter, STAT3 itself is phosphorylated by the JAKs at position Y705, dimerizes, and translocates into the nucleus. At this point, it serves as a regulator of the expression of different STAT3 responsive genes. One prominent downstream gene is the suppressor of cytokine signaling 3 (SOCS3), which itself acts as a potent negative regulator of the leptin signaling, by binding of Y985 domain and following inhibition of JAK2. Protein tyrosine phosphatase 1 B (PTP1B), produced in the endoplasmic reticulum (ER), is further able to inhibit leptin signaling by dephosphorylating JAK2. Besides STAT3, STAT5 is also known to be activated and phosphorylated in vivo. Another downstream signaling branch of leptin is the Mitogen-activated protein kinase (MAPK) pathway. Here, the SH2 domain of the phosphatase SH2- containing protein tyrosine phosphatase 2 (SHP2) binds to pY985, becomes phosphorylated by JAKs, which finally activates MAPK extracellular signal-related kinase (ERK1/2) via recruitment of growth factor receptor-bound protein 2 (Grb2). The phosphatidylinositol 3 kinase (PI3K) signaling pathway is activated by leptin. IRS 2 (insulin receptor substrate 2) binds to ObRb through the SH2B1 domain, able to interact and upregulate JAK2. Those IRS proteins are then capable of binding and activating PI3K yielding the subsequent accumulation of phosphatidylinositol 3,4,5-triphosphate $\left(\mathrm{PIP}_{3}\right)$ and activation of 3-phosphoinositide- dependent protein kinase (PDK1) and Akt. The latter inhibits forkhead box O1 (Foxo1), the mediator of the previously mentioned function of leptin in the hypothalamus. Another component downstream of Akt is the Ser/Thr kinase mTOR (mammalian target of rapamycin), another sensor of the availability of nutrients and stimulator of cell growth, protein biosynthesis, and proliferation. The AMPK (adenosine monophosphate-activated protein kinase) pathway is stimulated by leptin as well, but the outcome differs between the tissues. While activated in hepatocytes and muscle, AMPK is inhibited in the hypothalamus, resulting in inhibition of food intake. 
Another important adipokine is Resistin, belonging to the cysteine-rich family of resistin-like molecules (RELMS) and named according to its connection to the resistance to insulin [69]. The ability to induce insulin resistance is associated with activation of SOCS3, an inhibitor of insulin signaling in adipocytes. However, this has so far only been observed in mice, not in humans [70]. Resistin levels are upregulated in the adipose tissue as well as in the serum of obese individuals [71]. The localization of resistin production seems to differ between mice and men: Whereas the synthesis in humans takes mainly place in macrophages and monocytes [72], it is in mice predominantly produced in adipocytes [73]. Furthermore, the human type only shares a $64 \%$ homology with the murine [74]. Nevertheless, it has a known pro-inflammatory effect in humans, since resistin stimulates the expression of TNF and IL-6 in mononuclear cells [75] as well as the expression of pro-inflammatory adhesion molecules vascular cell adhesion protein 1 (VCAM-1), intercellular adhesion molecule 1 (ICAM-1), and pentraxin in endothelial cells. Pentraxin directly counteracts adiponectin, an anti-inflammatory adipokine, and fosters the adhesion of leukocytes [76].

Visfatin, also known as nicotinamide phosphoribosyltransferase (NAMPT), represents another type of adipokine, mainly secreted by the visceral type of adipose tissue [77]. In humans, an elevated level of visfatin has been detected in obese and type 2 diabetes patients [78]. Moreover, a positive correlation between IL-6 and the c-reactive protein (CRP) has been observed, linking visfatin to inflammation [77]. In 1987, the first adipokine, adipsin, was described, also known as complement factor $\mathrm{D}$, a part of the alternative activation pathway of the complement system [79]. It is dysregulated in obesity and diabetes models [80]. In obese mice, circulating adipsin levels are decreased [81], whereas in humans a mild elevation could be observed [82]. In 2014, studying mouse models as well as diabetes patients, Lo et al. [83] could demonstrate that adipsin serves a connection between adipocyte function and $B$ cell physiology in the pancreas.

In this context, a number of studies have demonstrated that interferons (IFNs) are also released from adipose tissue [84]. Controversially, Surendar et al. showing that adiponectin reduces the IFNY level but the hypoleptinemia could be shown as responsible for the decrease of the IFNY response [85]. IFNY influences the function of adipocytes and promotes the inflammation of the adipose tissue [86]. Studies are showing a shift to the Th1-cytokine profile triggered by IFNY [87]. Particularly important is in the context of viral pneumonia that the IFN response is the most efficient innate immune response against viral infections [88] The inhibition of the viral replication mediates the antiviral effect, and primarily type I IFN (IFN $\alpha / \beta)$ plays a crucial role.

Adipocytes and stromovascular cells of the adipose tissue are addtionially able to produce the well-studied pro-inflammatory cytokine TNF [33]. Levels are clearly increased in the systemic circulation and adipose tissue in obese individuals as well as in models of type 2 diabetes [89]. TNF has also been proposed to play an important role in the development of insulin resistance since it debilitates the important tyrosine phosphorylation of the insulin receptor and its substrate IRS1 in muscle and adipose tissue [90].

Nearly one-third of circulating IL-6 is produced in visceral adipose tissue, where it is secreted mainly by macrophages and adipocytes [91]. The plasma levels again positively correlate with obesity in humans [92]. IL-6 also represents a link to insulin resistance, as it has been shown to suppress metabolic processes stimulated by insulin in hepatocytes, possibly induced by SOCS3 expression [93]. Elevated levels of IL-6 are likely connected to an increase in acute phase response proteins, such as CRP [25]. In addition to the abovementioned cytokines, IL-18 is produced in adipose tissues and shows increased levels in obese individuals [94]. In rodent models, this overexpression leads to a higher amount of cell adhesion molecules, the infiltration of macrophages, and vascular abnormalities [95].

Adipocytes and macrophages are further able to synthesize the retinol-binding protein 4 (RBP4); its levels are elevated under obese conditions and associated with features of the metabolic syndrome in humans [96-98]. Lipocalin 2 and angiopoietin-like protein 2 (ANGTPL2) are expressed in adipose tissue and positively correlated with adiposity, 
hyperglycemia, insulin resistance, and CRP levels in humans [99,100]. Additionally, the chemokines CCL2, also known as monocyte chemoattractant protein-1 (MCP-1) [101], and C-X-C-motif chemokine 5 (CXCL5) [102] are secreted by the adipose tissue. Ob/ob mutant or diet-induced mice (DIO) mice, as well as obese humans, express high levels of MCP-1. In mice, it has already been shown to activate macrophage recruitment and to promote inflammation, glucose intolerance, and insulin insensitivity [103]. Obese and insulin-resistant human individuals also show an increase in CXCL5 levels, a factor that is produced by macrophages within adipose tissue [102].

\subsection{Anti-Inflammatory Molecules of the Adipose Tissue}

The adipokine with the highest serum levels is adiponectin, which is almost exclusively synthesized by adipocytes [69]. After its discovery in 1995, Hu et al. [104] detected for the first time that obese mice and humans show a downregulated expression of adiponectin in adipose tissue. Conversely to this investigation, especially adipocytes in visceral adipose tissue are the main source of this adipocytokine [105]. It shows structural similarities to the complement factor $\mathrm{C} 1 \mathrm{q}$ and is also able to form similar complex structures, such as multimers [106]. Adiponectin has a molecular weight of $30 \mathrm{kDa}$ and accounts for approximately $0.01-0.05 \%$ of the plasma protein amount [107]. In the circulation, it is present in different forms, as low-, medium- and high-molecular weight (LMW, MMW, HMW) complexes [108]. Most notably, the HMW type is seen to be the most biologically active isoform [109]. Adiponectin exerts its main functions via the adiponectin receptors 1 and 2 (ADIPOR1 and ADIPOR2), which are expressed in various tissues [110]. The central functions of adiponectin are orchestrated via AMPK signaling [111].

Besides the detected downregulation of adiponectin in subjects with an increased body mass, especially the inverse correlation to glucose intolerance and type 2 diabetes is of importance [112]. In this context, adiponectin appears to promote beta-cell function and survival [113]. Furthermore, it increases insulin sensitivity in hepatocytes [114]. Apart from diabetes, low adiponectin levels are also associated with an increased risk for hepatic fibrosis [115] and cancer [116]. It was also observed, that an elevated level of adiponectin is associated with a decreased susceptibility for myocardial infarction in men [117]. Concerning pulmonary impairments, it is positively associated with lung function in healthy adults [118].

With regard to the inflammatory actions, there are different molecular actions known that suggest adiponectin as a potential antagonist of leptin. Clear anti-inflammatory properties through inhibition of IL-6 production, induction of anti-inflammatory cytokines, such as IL-10 or IL-1 receptor antagonist [119], and reduction in ICAM-1 and VCAM1 [120] were shown. Secondly, adiponectin levels are decreased in obese and type 2 diabetic subjects and are negatively correlated with visceral mass [121]. Furthermore, the expression seems to be downregulated by pro-inflammatory cytokines TNF $\alpha$ and IL-6 [106], hypoxia, and oxidative stress [122]. It also negatively correlates with the level of CRP in obese or diabetic conditions [106]. Adiponectin can also affect macrophages by stimulating the production of anti-inflammatory cytokines [123]. Along the same line, adiponectindeficient mice display an increased expression of pro-inflammatory M1 type markers and decreased anti-inflammatory M2 type markers [124].

In 2010, another anti-inflammatory adipokine, secreted frizzled-related protein 5 (SFRP5), was discovered [125]. The level of SFRP5 is downregulated in adipose tissue from obese rodents as well as from obese humans with insulin resistance [63]. A deficiency of this adipokine leads to an accumulation of macrophages resulting in increased proinflammatory cytokine production [63]. A clinical study furthermore demonstrated an association between lower SFRP5 levels in adults with impaired glucose intolerance and type 2 diabetes, as well as a negative correlation to increased BMI [126]. 
The overall dysregulation of secreted adipocytokines creates a low-grade chronically inflamed environment during weight gain conditions. This chronic inflammatory state is closely linked to the predisposition to various comorbidities of obesity: lower levels of adiponectin, for example, are known to lead to an elevated risk to develop cardiovascular diseases, such as hypertension [127] or myocardial infarction [117]. This dysregulation is further connected to the development of insulin resistance [128] and potentially impacts the comorbidities of cancer and asthma [31]. Moreover, a connection between this chronic state of low-grade inflammation and the susceptibility to viral or bacterial pulmonary infections seems likely. In Chapter 5, we summarize, connect, and compare different publications on pulmonary infections, the most frequent infection focus, and discuss obesity as a risk factor for severe infections. Different experimental setups to mimic obesity in vivo and in vitro are summarized in Chapter 4 beforehand.

\section{Experimental Model Systems to Study Molecular Effects of Obesity}

\subsection{In Vivo Models}

In the last decades, a variety of rodent models aiming to mimic the human pathophysiology of obesity have been developed. They can be either of monogenic or polygenic origin [129]. The most prominent monogenic obesity model is the $o b / o b$ mouse characterized by a global lack of leptin on protein- but not mRNA-level [130,131]. Based on this mutant and parabiosis experiments, leptin was discovered in 1994 [44]. The ob/ob mutant displays very prominent obese phenotypes that include induction of metabolic alterations such as insulin resistance and hyperglycemia, and can vary in different mice strains [132]. A second strain used for parabiotic experiments, the $d b / d b$ mouse, shows the same obese phenotype. In this case it is not orchestrated by the absence of leptin protein but by a global lack of the leptin receptor. Since this mutant is further defined by early-onset and severe progression of diabetes, it is more commonly used in the diabetes context than in obesity research per se [133]. In $C P E^{\text {fat/fat }}$ mice, an obese phenotype with diabetes is induced by the fat mutation in the Carboxypeptidase E (cpe) gene, an enzyme important for the synthesis of insulin [134]. Another rodent model is the Zucker rat, discovered by Zucker and Zucker in 1961 [135]. This strain is defined by a homozygous mutation in the gene fatty $(f a / f a)$, leading to a deregulated food intake via defects in the leptin signaling. The Zucker rat mimics the state of hyperleptinemia and further develops insulin resistance but no diabetes [129].

Monogenic models, however, cannot fully resemble the origin of obesity in humans, because only a small proportion of obese individuals actually feature mutations in leptin or its receptor [136]. In contrast, people with an obese phenotype display a leptin resistance, defined by high protein levels in the circulation with no means to respond appropriately $[137,138]$. The DIO mouse is a prominent, polygenic obesity model, resembling the human pathophysiology much closer. The overall outcome of the diet varies according to the type and composition of food and the rodent strain utilized [129]. Frequently, fodder is used that is predominantly composed of soybean and lard with a kcal fat content of either $45 \%$ or $60 \%$ [129]. Another polygenic diet-based model is the Cafeteria DIO. Here, more enjoyable food, like candy, is given additionally to normal fodder resulting in a more humanized eating behavior [139]. However, problems in standardization are considerable drawbacks. The DIO concept was further improved in rats by Levin and colleagues in 1989. The group started to mate mice with an equal weight status after the high-fat diet (HFD) period. Following outbreeding, offspring from the obesity-prone group had a higher probability to gain weight during HFD from a very early stage on [140].

Although, rodents can present a suitable model for human obesity in some settings, the effort and costs to provide appropriate husbandry conditions are rather high. Therefore, other in vivo approaches using non-mammalian models are in use: Especially the zebrafish shows a variety of synergies with mammals, in particular regarding adipose tissue and lipid metabolism, making it a promising alternative in vivo model to study obesity [141]. Its high 
reproduction rate, low husbandry costs, and phenotypical transparency enable large-scale experiments, for instance, in the framework of anti-obesity drug development [142].

\subsection{In Vitro Models}

Even though valuable insights on the molecular effects of obesity could be gained from animal models, there is an urgent need for alternative model systems allowing humancentric research. Despite the increasing humanization of animal models, there still are major physiological discrepancies. Especially with regard to metabolism, functioning of the immune system, and general response strategy to infections, mice differ significantly from humans [143-145].

However, establishing a suitable human cell source for in vitro model is a major challenge. Even in the case of ready abundance of adipose tissue as a byproduct of cosmetic surgeries, for instance, culturability aspects including expandability or cryopreservation of cells restrict full flexibility. Alternatively, human cell lines are broadly used; however, these cell lines are mostly derived from cancerous tissues. A very promising approach merging the advantages of both human primary cells and cell lines is the stem cell (SC) technology. Despite the speedy progress and daily achievements in the field, the maturity of SC-derived cells, e.g., adipocytes, is often still insufficient: Adipocytes derived from stem cells or pre-adipocytes in vitro were found to (i) hardly reach a state of unilocularity (i.e., their lipids are stored in multiple smaller vacuoles as compared to the mature adipocyte phenotype of just one large lipid vacuole) and, (ii) to secrete adipose-associated messenger molecules at very different proportions than in vivo [146]. While both phenomena reflect an immature adipocyte state, the latter in particular renders an in vitro differentiation of adipocytes unsuitable when studying molecular patterns of obesity, which is characterized by altered cytokine and hormone profiles $[147,148]$.

Advanced 3D systems, such as organoid technology, often lack key in vivo microenvironment characteristics including vascular perfusion, mechanical cues, tissue-tissue interfaces and recapitulation of immune aspects. A step further towards a physiologically relevant in vitro culture system presents the Organ-on-Chip (OoC) technology. OoCs are microfluidic devices that are capable of emulating human biology in vitro at the smallest possible scale. Alongside three-dimensionality, on-chip microenvironments tailored to specific organs, as well as physiological cell-cell interactions, OoCs enable the application of dynamic fluid flow. Especially in combination with both the iPSC and organoid technologies, OoCs have the potential to lead to a paradigm shift, moving non-clinical research from animal models to advanced human-based in vitro systems $[149,150]$.

Adipocytes are a unique set of cells that are capable of storing large amounts of intracellular lipids without being damaged. However, these unique characteristics of mature adipocytes pose challenges when they are supposed to be cultured in vitro, the most severe being an enormous fragility and size (up to $200 \mu \mathrm{m}$ cell diameter; almost the entire cell body consists of one large lipid vacuole) as well as buoyancy in aqueous liquids owing to the lipid content. Moreover, mature adipocyte in vitro culture is limited by a nonproliferative and non-cryopreservable status of the cells making donor-specific experiments almost impossible. As a result, it comes as no surprise that many of the existing adipose in vitro models rely on an in vitro differentiation of stem cells or adipose progenitor cells into adipocytes. Pre-adipocyte-derived adipose organoids, for instance, constitute simple but promising 3D models to study adipose inflammation [151-153]. Hence, unless studying aspects of adipogenesis, as done in many models discussed in a recent review [146], a conservation of maturity of primary adipocytes in vitro defines the cell source of choice when studying impacts of adipose tissue function.

To date, research in the field of adipose tissue in vitro models is rather sparse in comparison to other organ systems. In addition, the majority of adipose tissue engineering aims at the development of large-scale tissue for use as grafts, rather than focusing on research of adipose tissue (patho-) physiological mechanisms. As discussed above, conventional dish culture of mature adipocytes is not possible owing to buoyancy and fragility 
issues. One common solution to handle mature adipocytes ex vivo/in vitro is the use of 3D scaffolds from various biomaterials [154-157]; silk [154,155,158], modified cross-linkable gelatin [156] or collagen [157]. A further approach towards engineering structural support for adipocytes is the so-called sandwiched WAT (SWAT): primary human adipocytes are cultured in between two tissue-engineered sheets from adipose-derived stromal cells [159]. Compared to approaches creating mechanical support, other concepts even take advantage of the mature adipocytes' buoyancy. Based on adipocyte floating culture, Harms et al. [160] introduced a versatile technique to culture and maintain identity and function of mature adipocytes from various origins (murine vs. human, subcutaneous vs. visceral, and lean vs. obese), dubbed 'membrane mature adipocyte aggregate cultures' (MAACs) (Figure 3A).

While the previously discussed 3D in vitro models integrating mature adipocytes present valuable advances in terms of long-term culturability, they still fall short of mimicking physiological adipose tissue microenvironment as well as vasculature-like perfusion. Since comprehensive reviews on adipose tissues-on-chip were published only recently $[147,161]$, we will highlight solely a few examples which exhibit the greatest potential for studying the influence of adipose tissue on lung physiology.

A key aspect to studying molecular patterns of obesity is the preservation of physiological hormone and cytokine secretions in vitro as well as suitable means for assessing these secretions. Thus, for the interrogation of adipocyte functionality, microanalytical fluidic systems (MAS) are of utmost value: One of the first MAS allowed for time-resolved sampling of factors secreted by endocrine tissues, such as adiponectin [162]. More advanced devices based on droplet microfluidics significantly increased the time-resolution of the secretion sampling [163]. Combined with on-chip enzyme assays, the droplet-based sampling approach enabled monitoring of glycerol secretion from adipocytes at a $3.5 \mathrm{~s}$ temporal resolution (Figure 3B) [164].

While these microanalytical microfluidic devices have a great potential for assessing highly temporally resolved secretion readout, they are less suited for long-term culture of tissues on-chip and for studying the interaction with other tissue types. The majority of adipose-tissue-on-chip culture systems introduced so far are based on in vitro differentiated adipocytes [146]. Owing to the vast prevalence of type 2 diabetes, studying molecular mechanisms of adipose inflammation in the context of insulin resistance weighs heavy in the field of adipose tissue research. Accordingly, a number of adipose tissue OoCs with a focus on adipose-immune interaction were developed. Zhu et al. [165] co-cultured mouse adipocytes derived from the 3T3L1 precursor cell line and macrophages (J774A.1 cell line) in a microfluidic platform with integrated biosensors for cytokine detection (Figure 3C). Upon injection of stimulating factors, they were able to detect in situ the kinetics of pro-inflammatory (TNF- $\alpha$ and IL-6) and anti-inflammatory (IL-10 and IL-4) cytokines. Liu et al. [166] co-cultured human pre-adipocyte-derived adipocytes and macrophagelike cells (U937 cell line) in two different compartments of a microfluidic platform and measured the cytokine release and glucose uptake. Given the importance of physiological hormone and cytokine secretion profiles from adipose tissue, the integration of mature adipocytes into OoC platforms will be crucial when studying the effects of molecular secretions of adipose tissue on other organs in vitro. An OoC that accommodates mature human adipocytes was recently introduced [167] r: in a microfluidic platform specifically tailored to the requirements for adipocyte culture. The viability and functionality of mature adipocytes isolated from human subcutaneous adipose tissue could be maintained for up to 5 weeks (Figure 3D). Although being able to include mature adipocytes, this system still does not fully recapitulate in vivo adipose tissue since it lacks further cell types such as adipose tissue macrophages and endothelial cells, especially of interest for studying adipose tissue inflammation and obesity. 
A. 3D culture of floating adipocyte aggregates (Harms et al. 2019)

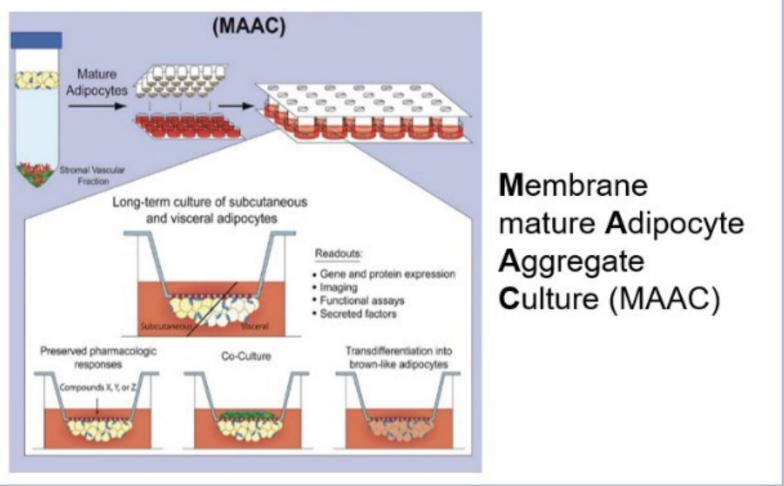

C. Adipose-inflammation model (Zhu et al. 2018)

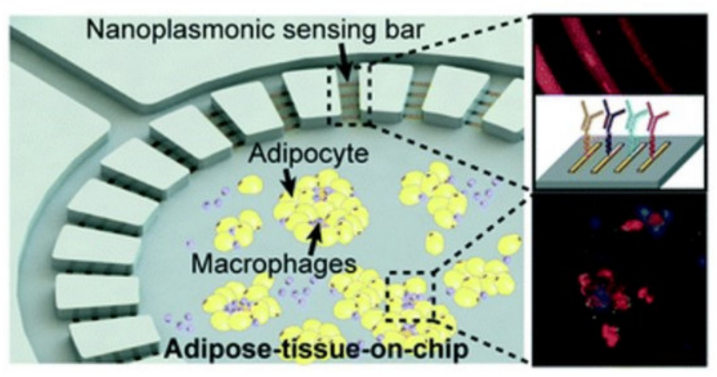

B. Microanalytical platform for secretion sampling (Hu et al. 2020)

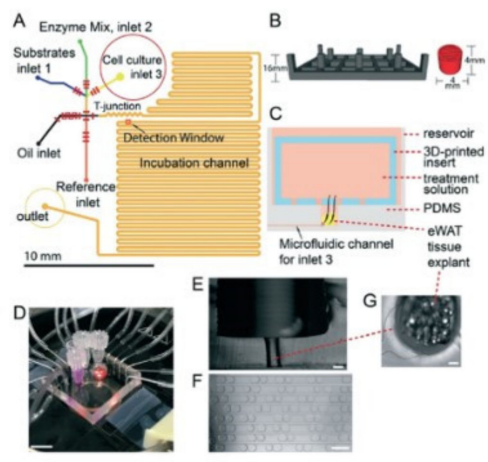

D. Human mature adipocytes-on-chip (Rogal et al. 2020)

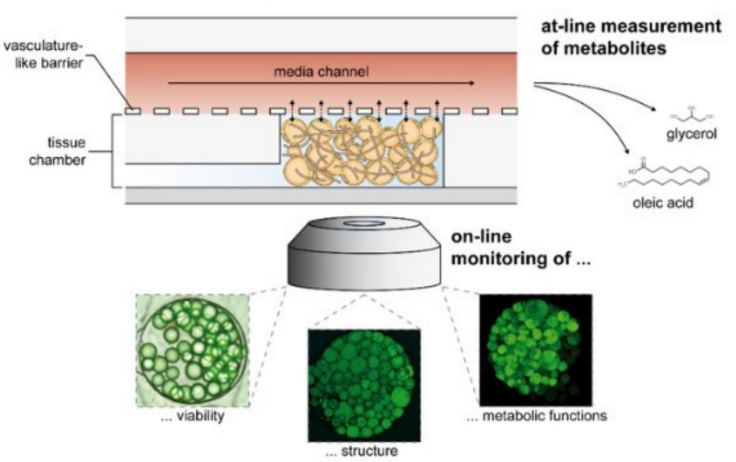

Figure 3. Adipose tissue in vitro models (A) Membrane mature adipocyte aggregate cultures (MAACs) enabling long-term culture of buoyant primary adipocytes. Reproduced and slightly modified from [160] (CC BY 4.0); (B) Microanalytical fluidic system for the monitoring of glycerol secretion from adipocytes at a $3.5 \mathrm{~s}$ temporal resolution. Reproduced from Ref. [164] with permission from The Royal Society of Chemistry; (C) Organ-on-chip for studying adipocyte-immune interaction with integrated biosensors for cytokine measurement. Reproduced from Ref. [165] with permission from The Royal Society of Chemistry; (D) Adipose-on-chip integrating human mature adipocytes into a micro-physiological environment featuring vasculature-like perfusion. Reproduced from reference [167] (CC BY 4.0)".

Besides the recapitulation of the local micro-physiological environment, a further unique aspect of the $\mathrm{OoC}$ technology is the capability to connect different tissues with each other, enabled by the vasculature-like perfusion [168]. These multi-organ-chips allow the study of tissue-tissue interactions [169], investigation of pharmacokinetictics of drugs [170] and modeling of systemic diseases such as diabetes [150]. In the context of the impact of obesity on bacterial and viral lung infections, two-organ-chips integrating adipose and lung tissue could potentially path the way for entirely novel types of mechanistic studies with direct human-relevance.

In conclusion, a number of adipose tissue-on-chip and advanced 3D adipose tissue culture models have emerged in the past years. These systems address many of the limitations of animal models and clinical studies by providing human-relevant models amenable for patient-specific experimental studies on a mechanistic level. The majority of the models study inflammation within the scope of insulin resistance/diabetes. However, they also provide a great potential to study how the low-grade inflammation in obesity affects lung infection, especially when connected to lung-on-chip models [171]. 


\section{Pulmonary Infections and the Impact of Obesity}

Infections in the pulmonary tract can be either of bacterial or viral origin. In the following, we summarize observations and interpretations from clinical and more experimental studies in order to further elucidate obesity as a risk factor in both infection scenarios, as summarized in Figure 4.

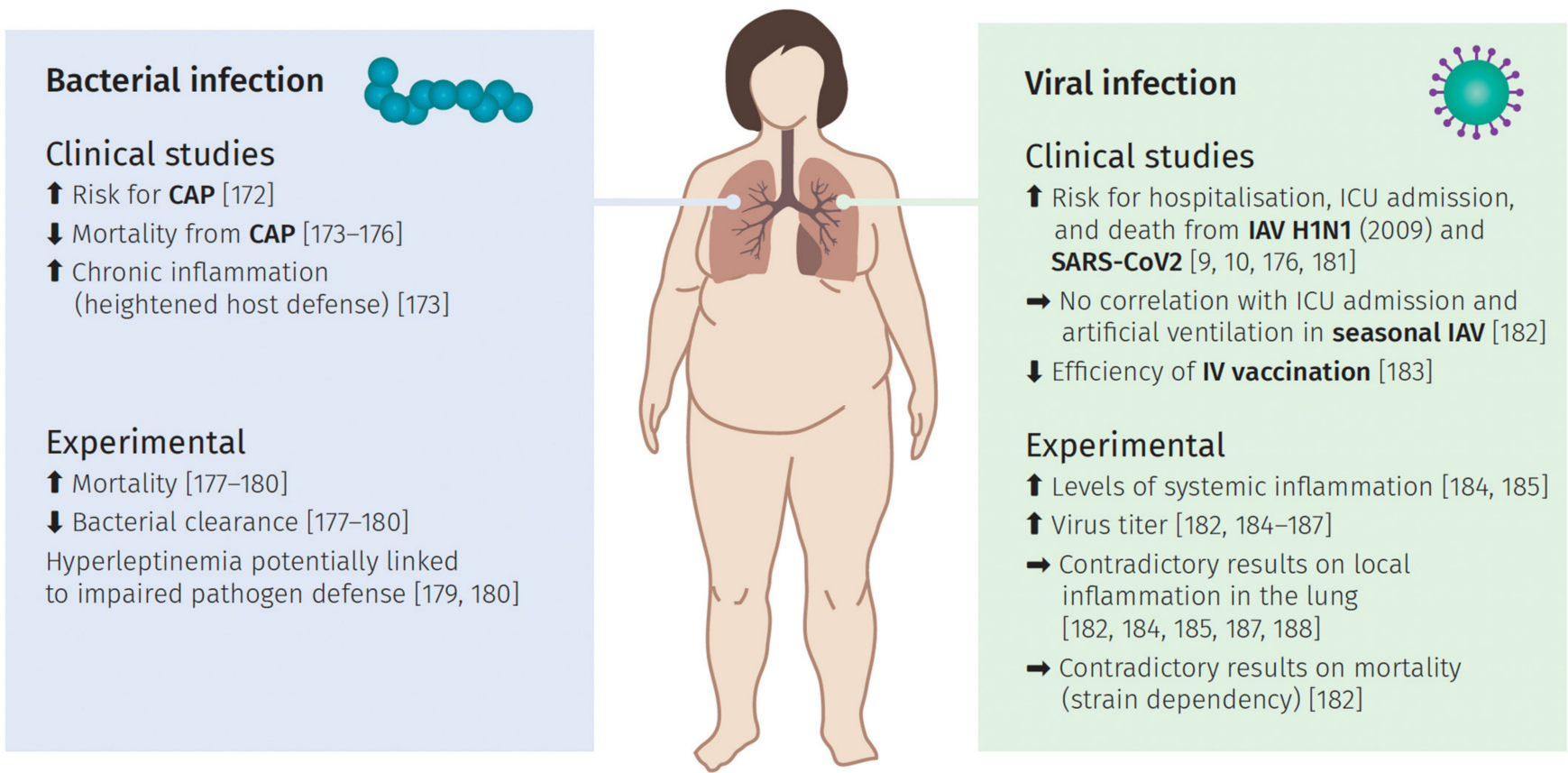

Figure 4. The impact of obesity and bacterial and viral infections. Overview of observations gained from clinical studies and experimental approaches regarding bacterial and viral infections in obese subjects with corresponding sources.

\subsection{Bacterial Lung Infection}

Investigating potential correlations between weight, infection risk, and overall mortality in clinical studies is the most straightforward approach to analyze obesity as a potential risk factor for the development of bacterial infections. In the case of community-acquired pneumonia (CAP), mainly caused by bacteria like Streptococcus (S.) pneumonia [172], the results are in general following a clear trend; although they are in part contradictory.

Data of various groups are pointing towards the so-called "obesity paradox". This paradox describes the observation that an obese weight status can be protective in some health concerns, which is also observed in case of non-infectious conditions such as heart disease [11] or end-stage renal disease [173]. Supporting this hypothesis for CAP, CorralsMedina et al. [174] could show that an increased BMI is associated with reduced 30-day mortality; confirmed in a larger sample size via a clinical study by Singanayamagam et al. [175]. Similar results were reported for 1-year [176] and 6-year mortality rates [177]. Interestingly, one study also reported higher CRP levels in obese subjects [175]. This suggests higher levels of inflammation, which were assumed to possibly improve outcomes via immunomodulation in severe cases. In stark contrast, Chen et al. [176] did not observe this effect, but determined CRP levels as one of the seven risk factors besides obesity for increased 1-year mortality and suggested a potential association between those parameters. Singanayamagam et al. [175] further argued that the state of chronic inflammation in obese patients could be a reason for a generally activated state of host defense. Even though, there are some limitations to this study (e.g., potentially misdiagnosed CAP in obese patients), these very recent findings seem to support the concept of the obesity paradox during CAP.

Contradictory to that, a prospective study showed a direct association between excessive weight gain and a nearly twofold higher risk of CAP in women in the US [178]. The limitation of this study is the lack of etiological analysis. The causative pathogen was 
not identified; thus, it is unclear whether viral or bacterial pneumonia was the trigger. In addition, previous antibiotic treatment or vaccination was disregarded.

To unravel the possible connections between obesity and the risk of bacterial pneumonia/lung infection or associated mortality, further studies tried to examine the underlying inflammatory profiles in various in vivo models infected with different pathogens.

Ob/ob mice infected either with S. pneumonia [179] or Klebsiella (K.) pneumonia [180] displayed higher lethality or mortality and reduced bacterial clearance in lung and blood in comparison to lean mice. While the number of leukocytes and the level of TNF- $\alpha$, IL-12, and CXCL-2 cytokines were not altered two days after infecting ob/ob mice with K. pneumonia, alveolar macrophage phagocytosis and leukotriene B4 synthesis were impaired [180]. Infection of $o b / o b$ mice with S. pneumonia, however, caused increased levels of TNF- $\alpha$, macrophage inflammatory protein 2 (MIP-2), and prostaglandin E2 (PGE2) as well as a greater number of leucocytes after two days [179]. When analyzing the impact of obesity on S. pneumonia infection with the CPE $\mathrm{E}^{\mathrm{fat} / \mathrm{fat}}$ mouse model [181], neither differences in survival, in bacterial burden, nor in lung or serum cytokines could be observed [181]. Although some of these findings indicate a link between bacterial infections and obese states, the observations differ depending on the type of bacteria and the model used for the obese phenotype.

The importance of the employed model was highlighted in a study by Ubags et al. [182] that infected four common mouse models (ob/ob, $d b / d b, C P E^{\text {fat } / f a t}$, and DIO) with K. pneumonia. While all showed impaired clearance and neutrophil chemotaxis, they also exhibited differences in granulocyte-colony stimulating factor (G-CSF) mediated survival, cytokine transcription, MAPK, and STAT3 activation. Moreover, temporal variations of the host defense between the groups were observed, which was interpreted as either different bacterial handling by the four models in an early and a late phase or the "plateau" phenomenon. This phenomenon implicates that the bacterial burden of the lung cannot rise above a particular degree in obese mice. Thus, this study showed an impaired pulmonary host defense after bacterial infection, mainly associated with impaired cytokine production or chemotaxis of neutrophils, but also highlighted the variations between the mouse models. Considering all the metabolic discrepancies between the examined models, results from studies using different models should be interpreted with care.

Escherichia (E.) coli is another important pathogen rather causing the nosocomial type of pneumonia [183] The impact of obesity on this kind of infection has also been studied with the help of the DIO mice model [184-186]. Before the initial infection after the highfat diet, similarly increased levels of triglycerides, cholesterol, leptin, or IL-6 have been detected [184,185]. In a study by Wan et al. [161,185], mild and severe infections were modeled using two different dosages of the pathogen. The higher pathogen doses resulted in a higher mortality and lung injury in DIO mice, but the difference in E. coli counts compared to controls was not observed. Inoculation with lower CFU led to reduced $E$. coli burdens, less severe lung injury, but greater numbers of immune cells and lower IL-10 and TNF- $\alpha$ concentration in DIO mice compared to lean type. These observations support the hypothesis that during mild infections, obesity is protective, comparable to trends observed regarding the obesity paradox in CAP, but in more severe conditions it might weigh down the host defense. Wang et al. [184] observed a temporal shift in inflammatory signals peaking at $12 \mathrm{~h}$ post-infection with $E$. coli in the lean and at $72 \mathrm{~h}$ in the DIO mice cohort. This temporal delay was also detected for apoptotic markers within pulmonary cells in the same experimental setup [186].

When interpreting observations in the $o b / o b$ mouse model, it is important to keep in mind that they have an obese phenotype caused by genetic ablation of leptin production. This lack of leptin contrasts the high levels in the circulation and their positive correlation with adipose tissue mass in obese humans [129]. Nevertheless, the ob/ob mouse model helps to analyze the function of leptin in reactions to infection of the lung. For example, Hsu [179] and Mancuso et al. [180] were able to show that a lack of leptin impairs different aspects of the host defense and that the administration of exogenous leptin was sufficient to 
restore this defect during infection with S. pneumonia and K. pneumonia. Even though these results underline the role of leptin during bacterial lung infection, they do not represent a clear link between obesity and lung infection. However, these findings could be of clinical relevance as a potential treatment option for patients with bacterial pneumonia, especially in immunocompromised individuals.

Ubags et al. [187] provided a different hypothesis of the role of leptin for pulmonary host defense: They suggested that rather a hyperleptinemia than high BMI might serve as a link to an impaired pulmonary pathogen defense and increased susceptibility to infection. In two patient cohorts, they could observe a positive correlation between plasma leptin levels and the risk of respiratory infection and further with mortality in patients with severe pneumonia resulting in ARDS. They substantiated these findings by showing a stronger association between leptin levels and lung bacterial burden in DIO mice challenged with $K$. pneumonia than with their body weight. Furthermore, lavage neutrophils of obese and lean mice showed a strong inverse association between neutrophil counts and plasma levels of leptin. To finally separate hyperleptinemia from obesity, they created a hyperleptinemic but lean mouse model. Isolated hyperleptinemia resulted in an increase in lung bacterial colony-forming units (CFU), a decrease in bronchoalveolar lavage (BAL) neutrophil count, and impaired function. In summary, these results indicate that the adipocytokine leptin itself might alter the pulmonary host defenses resulting in increased susceptibility to and mortality from bacterial respiratory infections in obese patients.

To date, no unifying concept can be established based on the summarized findings. The "obesity paradox" seems to hold true for most of the clinical studies performed but the underlying molecular mechanisms still remain unclear. However, it should be considered that the investigated protective role is solely based on correlations to the BMI, a very simple classification of obesity (see chapter 2). In this context, Despres [188] concluded, that the obesity paradox should be rather seen as a BMI paradox. This could also hold true for the protective role in CAP, as especially the body fat composition and distribution change the inflammatory fate of adipose tissue. Attempts to elucidate the mechanisms resulted in contradictory findings. These contradictions, however, are clearly connected to the choice of in vivo model and the pathogen used for the lung infection. Regarding the potential impact caused by the dysregulated adipocytokine network, solely the impact of leptin could be elucidated utilizing $o b / o b$ mice. However, there is still the need to further analyze these molecular interactions.

\subsection{Viral Induced Lung Infection}

The majority of respiratory infections are caused by viruses. In particular, the RNA viruses influenza and coronavirus have a large socio-economic impact and are able to cause serious infection courses.

The annual influenza season is a constant in our health care system. It can result in either a mild infection or, in the worst case, severe viral pneumonia. This has led both to the development of diagnostic methods and annual vaccination options as well as to a comprehensive understanding of the infection process of this special type of human pathogen. The emergence of a novel H1N1 IAV strain in California and Mexico in 2009 resulted in the first pandemic influenza period of the 21st century [189]. The virus spread rapidly around the world, leading to 74 countries and territories confirming infections in June 2009 according to the WHO. Genome analyzes of the virus revealed a non-human origin and a relation to known viruses circulating in pigs. The North American H3N2 triple-reassortant, the classical H1N1, and the Eurasian 'avian-like' swine H1N1 viruses comprise the origins of the new subtype, able to infect humans [190,191]. The analyzes of the epidemiological profile of infections with this new subtype allowed new insights like the identification of new potential risk factors. At first, these data showed a change in the age distribution, as in the US $60 \%$ of the patients were not older than 18 years and only $5 \%$ of the infections occurred in patients older than 50. Besides other well-characterized risk factors, obesity appeared as an additional risk factor for the first time [192]. 
In an extensive meta-analysis, Fezeu et al. [193] included articles from the USA, Ireland, France, and the Netherlands, all aiming to analyze the connection between obesity and influenza A virus (IAV) infection. By analyzing correlations between confirmed IAVinfection, hospitalization, admission to ICU, and body weight status of the patients, they concluded an elevated risk for ICU admission and overall mortality for extremely obese patients (BMI higher than 40). In addition, patients with a BMI higher than 30 showed a moderately but not significantly increased risk for ICU admission and death [193]. In line with these findings, another case-cohort study compared data from the pandemic series of 2009 with another cohort from 2003 to 2006 and confirmed the link between particularly strongly obese individuals and hospitalization and ICU admission [194]. The results from the examination of Braun et al. [195] highlight the differences between the pandemic in 2009 and seasonal IAV. For seasonal IAV, no correlation between obesity and admission to ICU or artificial ventilation could be detected; instead, a rather decreased risk for the development of pneumonia caused by seasonal IAV infection was connected with obesity.

This apparent strain dependency was substantiated in an experimental in vivo study infecting DIO mice either with a pandemic strain from 2009, a seasonal H1N1 strain, or a highly pathogenic Sw31. Increased mortality in obese mice compared to the corresponding lean control group was solely seen for infections with the pandemic strain [196]. Other groups confirmed the increased mortality in response to infection with a pandemic IAV strain in DIO mice [197,198]. Similar results were obtained with $d b / d b$ mice [199]. Further experimental steps addressed the elucidation of molecular events underlying the observed differences in survival, e.g., by monitoring pro-inflammatory cytokines present in the serum of infected obese and lean mice. In the DIO mouse, infection with IAV led very early to a significant elevation of systemic pro-inflammatory cytokines, like IL- $1 \beta$, TNF- $\alpha$, IFN- $\gamma$, and IL-6, in obese mice compared to non-obese mice [196,197].

Investigation of local molecular alterations within the pulmonary tract showed a significant elevation of active viral particles at day 4 p. i. in mice with DIO [197]. The same effect could be observed in the $d b / d b$ mouse model [199]. However, several other studies found no evidence for alteration of active viral particles within the lung with monitoring starting from day 2 until day 9 p.i. [196,198,200].

Regarding the inflammation profile during the infection, Zhang et al. [197] and Milner et al. [198] could clearly show a heightened local inflammatory state within lung tissue, e.g., by the elevation of the cytokines IL-6 at 4 days p.i. and further upregulation of the chemokines MCP-1 and KC at day 8 within the infected lung of obese mice These results are contrasted by several studies reporting lowered levels of cytokines $[196,199,200]$. In particular, Smith et al. [200] detected decreased amounts of IL-6, TNF $\alpha$, IL-1 $\beta$, and IL-10 in obese mice's lungs as well as lowered levels of the chemokines MCP-1 and RANTES. These observations, i.e., the downregulation of pro-inflammatory cytokines, are discussed as a potential explanation for the reduced viral clearance in obese mice. One potent contributor to the lowered inflammatory milieu might be a decreased infiltration with macrophages, the main source of pro-inflammatory cytokines during lung infection [201]. This suggestion is in accordance with the reduced amount of monocytes differentiating into macrophages detected in obese patients compared to normal-weight individuals [202].

Regarding systemic leptin levels during infection with IAV, findings are quite variable, including both reports of upregulation of leptin in lean mice only and of constant leptin levels during infection [196,197,200]. Elevated amounts in the circulation could, in principle, influence the inflammatory processes and viral spreading within the pulmonary tract. Elevated levels of leptin in the pulmonary tract could also result in an upregulation of its downstream signaling branches, e.g., the negative regulator SOCS3. SOCS proteins are also activated by different cytokines such as IL- 6 and IL-4 via JAK/STAT and play an important role in immunity [203]. The ability to likewise inhibit the signaling of these cytokines highlights the cross-regulatory role of the signal mediator SOCS [204]. Moreover, it has been shown that SOCS1 and SOCS3 suppress the type I IFN response, a central defense system against viral infections [205], e.g., in case of IAV infection [206]. According 
to these findings, Smith et al. were also able to detect a downregulation of IFN $\alpha$ and IFN $\beta$ in the lungs of obese mice after infection with PR8. In this context, Lui et al. [207] determined a reduction in virus titer in a corresponding SOCS3-knock-out mouse strain. Thus, the upregulation of SOCS3 as one explanation for the leptin resistance could lead to the downregulation of pro-inflammatory signaling processes and via that support the viral replication within the lung.

However, there is also evidence supporting a differing role of leptin signaling during infection of obese mice's lungs. As mentioned above, mice with a global loss of the leptin receptor showed reduced viral clearance. The same study, however, detected improved survival in mice that were solely leptin receptor-deficient in lung epithelial cells, alveolar type II cells, and monocytes suggesting, that leptin signaling in these cells enables a higher number of viral particles [199]. Moreover, treatment of obese mice with anti-leptinantibodies resulted in improved survival and downregulated cytokine levels, emphasizing again the role of leptin in obese mice during the course of infection. Nevertheless, leptin administration did not result in enhanced viral clearance [197].

A study from Paich et al. [208] addressed another important aspect, the impact of obesity on immune cells of patients in response to pandemic H1N1 (pH1N1). With the help of the ex vivo infection of peripheral blood mononuclear cells (PBMCs) from patients with different body weight status, they observed a dysregulation and lowered activity of CD4+ and CD8+ T cells in obese and overweight. These results are in line with the inefficient response to vaccination in obese individuals, already described in a prospective observational study [209]. To elucidate this connection, several studies were performed in mouse models. DIO mice that were previously immunized with commercial monovalent 2009 H1N1 vaccine showed a lowered antibody response and neutralizing capacity, resulting in elevated viral titers, more severe lung pathology, and inflammatory response after infection with H1N1 [210]. Karlsson et al. [208] reasoned that this could be due to an impaired memory response in obese mice, since molecular alterations were detected in response to a secondary infection with an H1N1 strain after a previous H3N2 infection. Furthermore, interferences within the antigen-presenting dendritic cells (DC) as important initiators of $\mathrm{T}$ cells were described, leading to alterations in the number and functionality of CD3 + and CD8+ T cells in lung tissue [211]. Kosaraju et al. [212] additionally determined disturbances in B cell activity both in obese humans and in obese mice.

In conclusion, results from both, clinical studies and in vivo obesity models, highlight the increased susceptibility for an IAV infection and decreased survival associated with obesity. Surprisingly, also a strain dependency of the effect, particularly for the pandemic strain of 2009, was discernible. Obese patients are not only at higher risk for an infection per se but also the lowered effectiveness of vaccination is an important issue for our health care system. So far, no clear concept of the molecular interplay between physiological effects of obesity and IAV infections could be established.

Besides an annual influenza season and recurring pandemics, we are currently experiencing a new coronavirus-triggered pandemic, with a novel coronavirus (SARS-CoV-2) causing the coronavirus disease (COVID-19) and challenging clinical management worldwide. Continuously rising numbers of clinical studies are being published worldwide that indicate risk factors for a severe course. These factors include pre-existing lung disease, neoplasms, age, but also overweight and obesity [213-215]. Clinical observations identified obesity as an independent risk factor for hospitalization, ICU treatment, and death $[9,10]$. Large cohort studies describe significantly elevated risks of intubation and death for obese COVID-19 patients [216-218]. Interestingly, younger obese individuals are particularly affected $[219,220]$.

Besides these clinical observations, Huizinga et al. [221] hypothesize that the inflammatory response of the obese tissue leads to a dysregulated immune response. Due to SARS-CoV-2 infections, cytokine storms are frequently reported [222]. Due to a large number of monocytes and macrophages in the fatty tissue, there is an increased activation, which further exacerbates the inflammation. In addition, the authors assume an impact on 
viral clearance caused by obesity. However, the detailed immune mechanisms are currently insufficiently clarified. Krams et al. [223] strongly emphasize the need to differentiate between visceral and subcutaneous adipose tissue. The authors highlight that primarily the visceral fat is linked to severe COVID-19 course of infection [224,225], as this tissue has an increased endocrinological activity [226].

A further essential aspect is the production of the transmembrane protein angiotensinconverting enzyme 2 (ACE2) receptors by the adipose tissue $[227,228]$. SARS-CoV-2 begins its replication cycle with the entry process into the host cell. For this, the binding of the spike glycoprotein to ACE2 is a crucial step [218]. Besides the lung, various tissues and organs express ACE2, and viral RNA has already been demonstrated in many extrapulmonary tissues [229]. Besides the small intestine and kidney, expression levels of ACE2 are particularly high in adipose tissue [230]. On this basis, adipose tissue could be actively considered as a replication site for the virus and thus become a source of viremic virus particles.

\section{Conclusions}

In this review, we summarized the role of obesity as a risk factor for pulmonary infections either of viral or bacterial origin. The most obvious effects stem from mechanical complications in the pulmonary tract impacting the susceptibility for infections. On a molecular level, the endocrine functionality of adipose tissue further influences pulmonary function and infections. We particularly focused on the dysregulation of these adipocytokines in the remodeling process during weight gain.

Particularly data gained from clinical studies highlight the impact of obesity on the course of respiratory infections. In the case of CAP, triggered by bacteria such as S. pneumonia, the results mainly point towards the well-described "obesity paradox", suggesting that high body weight is protective. For IAV infections, however, obesity was defined as an independent risk factor for severe courses following the pandemic of 2009. These contradictory findings highlight the differences between pulmonary pathogens and display the complexity of risk factor assessment. However, no unambiguous trend concerning the course of respiratory infections could be reasoned, neither regarding infections of bacterial nor of viral origin. With regards to the molecular changes resulting in a state of low-grade inflammation in obese patients, it is unclear whether this state is a benefit or a disadvantage in this setting. However, both pro- and anti-inflammatory stimuli influence the host and thus the course of a respiratory infection. These effects are variable in animal models based on the pathogen, the concentrations, but also the model used.

To study the impact of obesity, a variety of in vitro or in vivo model systems are used. Particularly rodents can mimic an obese weight status and associated physiological, pathological and molecular alterations. However, the translation to humans is often difficult and interpretations of the observations are dependent on the respective origin. Monogenic rodent models such as the prominent $o b / o b$ mice indeed feature a clear obese phenotype; polygenic more diet-based systems, however, seem to resemble the situation in obese humans better. Besides rodents, other model organisms such as zebrafish and drosophila are also utilized; So far, however, rather in the context of drug development than of infectious diseases. An alternative to animal models are in vitro models. Conventionally, 2D cell culture assays relying on (murine) cell lines or primary cells have been utilized. In recent years, technological advances such as iPS-cells, 3D-cell culture, and organ-on-chip have led to a novel generation of in vitro models that open up novel possibilities to study obesity and its impact on pulmonary infections.

It is well known that pulmonary infections are based on complex molecular interactions and immune reactions. Obesity influences a variety of physiological processes, including the dysregulation of signaling molecules, such as leptin. Hence, the elucidation of a clear molecular concept detailing the multistep processes of obesity and lung infections and their interactions is extremely complex. However, the ability of respiratory pathogens to cause pandemic episodes, as for IAV in 2009 and the current COVID-19 pandemic, em- 
phasizes the need for further mechanistic investigation of risk factors. The fact, that obesity on its own is a health problem of already pandemic measures in our century, additionally highlights the clinical relevance of the issues outlined in this review.

Author Contributions: Conceptualization, F.H. and S.D.-E.; methodology, F.H., S.D.-E.; data curation, F.H., S.D.-E.; writing—original draft preparation, F.H. and S.D.-E., J.R., P.L., B.L.; writing—review and editing, F.H., S.D.-E., B.L.; visualization, F.H., S.D.-E., J.R., P.L.; funding acquisition, S.D.-E., B.L. All authors have read and agreed to the published version of the manuscript.

Funding: This study was supported by the Federal Ministry of Education and Research (BMBF; 031L0247B to PL and NUM-COVID 19, Organo-Strat 01KX2021 to PL and SDE), FKZ 01EO1502 and by the Deutsche Forschungsgemeinschaft (DFG, German Research Foundation) under Germany's Excellence Strategy-EXC 2051-Project-ID 390713860. In addition, SDE was supported by the CSCC and IZKF (ACSP02). We acknowledge support by the German Research Foundation and the Open Access Publication Fund of the Thueringer Universitaets- und Landesbibliothek Jena Projekt-Nr. 433052568.

Institutional Review Board Statement: Not applicable.

Informed Consent Statement: Not applicable.

Data Availability Statement: Not applicable.

Acknowledgments: The authors want to thank Margit Leitner for the excellent illustrative design of the images.

Conflicts of Interest: The authors declare no conflict of interest. The funders had no role in the design of the study; in the collection, analyses, or interpretation of data; in the writing of the manuscript, or in the decision to publish the results.

\section{References}

1. Gray, D.S. Diagnosis and Prevalence of Obesity. Med. Clin. N. Am. 1989, 73, 1-13. [CrossRef]

2. Rosalki, S.B. The Clinical Biochemistry of Alcohol. In Scientific Foundations of Biochemistry in Clinical Practice; Elsevier: Amsterdam, The Netherlands, 1994; pp. 121-143. [CrossRef]

3. Obesity and Overweight. Available online: https://www.who.int/news-room/fact-sheets/detail/obesity-and-overweight (accessed on 7 November 2020).

4. Quetelet, L.A. A Treatise on Man and the Development of His Faculties. 1842. Obes. Res. 1994, 2, 72-85. [CrossRef] [PubMed]

5. Gadde, K.M.; Martin, C.K.; Berthoud, H.R.; Heymsfield, S.B. Obesity: Pathophysiology and Management. J. Am. Coll. Cardiol. 2018, 71, 69-84. [CrossRef] [PubMed]

6. Haslam, D.W.; James, W.P.T. Obesity. Lancet 2005, 366, 1197-1209. [CrossRef]

7. Koenig, S.M. Pulmonary Complications of Obesity. Am. J. Med. Sci. 2001, 321, 249-279. [CrossRef]

8. Robinson, J.; Swift-Scanlan, T.; Salyer, J.; Jones, T. The Obesity Paradox in Sepsis: A Theoretical Framework. Biol. Res. Nurs. 2020, 22, 287-294. [CrossRef] [PubMed]

9. Jackson-Morris, A.M.; Nugent, R.; Ralston, J.; Barata Cavalcante, O.; Wilding, J. Strengthening Resistance to the COVID-19 Pandemic and Fostering Future Resilience Requires Concerted Action on Obesity. Glob. Health Action 2020, 13. [CrossRef] [PubMed]

10. Noor, F.M.; Islam, M.M. Prevalence and Associated Risk Factors of Mortality Among COVID-19 Patients: A Meta-Analysis. J. Community Health 2020, 45, 1270-1282. [CrossRef] [PubMed]

11. Lavie, C.J.; Milani, R.; Ventura, H.O. Obesity, Heart Disease, and Favorable Prognosis-Truth or Paradox? Am. J. Med. 2007. [CrossRef] [PubMed]

12. Schwartz, A.R.; Gold, A.R.; Schubert, N.; Stryzak, A.; Wise, R.A.; Permutt, S.; Smith, P.L. Effect of Weight Loss on Upper Airway Collapsibility in Obstructive Sleep Apnea. Am. Rev. Respir. Dis. 1991, 144, 494-498. [CrossRef]

13. Olson, A.L.; Zwillich, C. The Obesity Hypoventilation Syndrome. Am. J. Med. 2005, 118, 948-956. [CrossRef]

14. Sharp, J.T.; Henry, J.P.; Sweany, S.K.; Meadows, W.R.; Pietras, R.J. The Total Work of Breathing in Normal and Obese Men. J. Clin. Invest. 1964, 43, 728-739. [CrossRef]

15. Fritts, H.W.; Filler, J.; Fisthman, A.P.; Cournand, A. The Efficiency of Ventilation during Voluntary Hyperpnea: Studies in Normal Subjects and in Dyspneic Patients with Either Chronic Pulmonary Emphysema or Obesity. J. Clin. Invest. 1959, 38, 1339-1348. [CrossRef]

16. Sharp, J.T.; Druz, W.S.; Kondragunta, V.R. Diaphragmatic Responses to Body Position Changes in Obese Patients with Obstructive Sleep Apnea. Am. Rev. Respir. Dis. 1986, 133, 32-37. [CrossRef] 
17. Dempsey, A.; Reddan, W.; Balke, B.; Rankin, J.; Ranrin, J. Work Capacity Determinants and Physiologic Cost of Weight-Supported Work in Obesity' Work Mpacity Determinants and Physiologic Cost of Weight-Supported Work in Obesity. J. Appl. Physiol. 1966, 21. [CrossRef]

18. Emirgil, C.; Sobol, B.J. The Effects of Weight Reduction on Pulmonary Function and the Sensitivity of the Respiratory Center in Obesity. Amer. Rev. Resp. Dis. 1973, 108, 831-842. [CrossRef] [PubMed]

19. Salvadori, A.; Fanari, P.; Mazza, P.; Agosti, R.; Longhini, E. Work Capacity and Cardiopulmonary Adaptation of the Obese Subject during Exercise Testing. Chest 1992, 101, 674-679. [CrossRef] [PubMed]

20. Vaughan, R. Volume and PH of Gastric Juice in Obese Patients. J. Am. Soc. Anesthesiol. 1975, 43, 686-689. [CrossRef] [PubMed]

21. Anderson, J.A.; McNicol, G.P. Preoperative Prediction of Postoperative Deep Vein Thrombosis. Br. Med. J. 1976, 2, 910-912. [CrossRef]

22. Goldhaber, S.Z. A Prospective Study of Risk Factors for Pulmonary Embolism in Women. JAMA J. Am. Med. Assoc. 1997, 277, 642. [CrossRef]

23. Williamson, J.A.; Webb, R.K.; Szekely, S.; Gillies, E.R.N.; Dreosti, A.V. Difficult Intubation: An Analysis of 2000 Incident Reports. Anaesth. Intensive Care 1993, 21, 602-607. [CrossRef]

24. Choban, P.S.; Weireter, L.J.; Maynes, C. Obesity and Increased Mortality in Blunt Trauma. J. Trauma Inj. Infect. Crit. Care 1991, 31, 1253-1257. [CrossRef]

25. Fantuzzi, G. Adipose Tissue, Adipokines, and Inflammation. J. Allergy Clin. Immunol. 2005, 115, 911-919. [CrossRef]

26. Nedergaard, J.; Bengtsson, T.; Cannon, B. Unexpected Evidence for Active Brown Adipose Tissue in Adult Humans. Am. J. Physiol. Endocrinol. Metab. 2007. [CrossRef]

27. Cinti, S. White, Brown, Beige and Pink: A Rainbow in the Adipose Organ. Curr. Opin. Endocr. Metab. Res. 2019, 4, 29-36. [CrossRef]

28. Himms-Hagen, J.; Melnyk, A.; Zingaretti, M.C.; Ceresi, E.; Barbatelli, G.; Cinti, S. Multilocular Fat Cells in WAT of CL-316243Treated Rats Derive Directly from White Adipocytes. Am. J. Physiol. Cell Physiol. 2000, 279. [CrossRef] [PubMed]

29. Boström, P.; Wu, J.; Jedrychowski, M.P.; Korde, A.; Ye, L.; Lo, J.C.; Rasbach, K.A.; Boström, E.A.; Choi, J.H.; Long, J.Z.; et al. A PGC1- $\alpha$-Dependent Myokine That Drives Brown-Fat-like Development of White Fat and Thermogenesis. Nature 2012, 481, 463-468. [CrossRef] [PubMed]

30. Giordano, A.; Smorlesi, A.; Frontini, A.; Barbatelli, G.; Cint, S. White, Brown and Pink Adipocytes: The Extraordinary Plasticity of the Adipose Organ. Eur. J. Endocrinol. 2014. [CrossRef]

31. Tilg, H.; Moschen, A.R. Adipocytokines: Mediators Linking Adipose Tissue, Inflammation and Immunity. Nat. Rev. Immunol. 2006, 6, 772-783. [CrossRef] [PubMed]

32. Weisberg, S.P.; McCann, D.; Desai, M.; Rosenbaum, M.; Leibel, R.L.; Ferrante, A.W. Obesity Is Associated with Macrophage Accumulation in Adipose Tissue. J. Clin. Invest. 2003, 112, 1796-1808. [CrossRef] [PubMed]

33. Frayn, K.N.; Karpe, F.; Fielding, B.A.; Macdonald, I.A.; Coppack, S.W. Integrative Physiology of Human Adipose Tissue. Int. J. Obes. 2003, 27, 875-888. [CrossRef] [PubMed]

34. Wellen, K.E.; Hotamisligil, G.S. Inflammation, Stress, and Diabetes. J. Clin. Invest. 2005, 115, 1111-1119. [CrossRef] [PubMed]

35. Calle, E.E.; Kaaks, R. Overweight, Obesity and Cancer: Epidemiological Evidence and Proposed Mechanisms. Nat. Rev. Cancer 2004, 579-591. [CrossRef] [PubMed]

36. Goossens, G.H. The Role of Adipose Tissue Dysfunction in the Pathogenesis of Obesity-Related Insulin Resistance. Physiol. Behav. 2008, 94, 206-218. [CrossRef] [PubMed]

37. Rosen, E.D.; Spiegelman, B.M. What We Talk about When We Talk about Fat. Cell 2014, 20-44. [CrossRef]

38. Virtue, S.; Vidal-Puig, A. Adipose Tissue Expandability, Lipotoxicity and the Metabolic Syndrome-An Allostatic Perspective. Biochim. Biophys. Acta Mol. Cell Biol. Lipids 2010, 338-349. [CrossRef]

39. Sun, K.; Scherer, P.E. Adipose Tissue Dysfunction: A Multistep Process; Springer: Berlin/Heidelberg, Germany, 2010 ; pp. 67-75. [CrossRef]

40. Sun, K.; Kusminski, C.M.; Scherer, P.E.; Sun, K.; Kusminski, C.M.; Scherer, P.E. Adipose Tissue Remodeling and Obesity. J. Clin. Investig. 2011, 121, 2094-2101. [CrossRef]

41. Wellen, K.E.; Hotamisligil, G.S. Obesity-Induced Inflammatory Changes in Adipose Tissue. J. Clin. Investig. 2003, 1785-1788. [CrossRef]

42. Lumeng, C.N.; Bodzin, J.L.; Saltiel, A.R.; Lumeng, C.N.; Bodzin, J.L.; Saltiel, A.R. Obesity Induces a Phenotypic Switch in Adipose Tissue Macrophage Polarization Find the Latest Version: Obesity Induces a Phenotypic Switch in Adipose Tissue Macrophage Polarization. J Clin Invest 2007, 117, 175-184. [CrossRef]

43. De Lorenzo, A.; Soldati, L.; Sarlo, F.; Calvani, M.; Di Lorenzo, N.; Di Renzo, L. New Obesity Classification Criteria as a Tool for Bariatric Surgery Indication. World J. Gastroenterol. 2016, 22, 681-703. [CrossRef]

44. Zhang, Y.; Proenca, R.; Maffei, M.; Barone, M.; Leopold, L.; Friedman, J.M. Positional Cloning of the Mouse Obese Gene and Its Human Homologue. Nature 1994, 372, 425-432. [CrossRef]

45. Kamran, P.; Sereti, K.I.; Zhao, P.; Ali, S.R.; Weissman, I.L.; Ardehali, R. Parabiosis in Mice: A Detailed Protocol. J. Vis. Exp. 2013, e50556. [CrossRef] [PubMed]

46. Coleman, D.L. A Historical Perspective on Leptin. Nat. Med. 2010, 1097-1099. [CrossRef] [PubMed] 
47. Tartaglia, L.A.; Dembski, M.; Weng, X.; Deng, N.; Culpepper, J.; Devos, R.; Richards, G.J.; Campfield, L.A.; Clark, F.T.; Deeds, J.; et al. Identification and Expression Cloning of a Leptin Receptor, OB-R. Cell 1995, 83, 1263-1271.

48. La Cava, A.; Matarese, G. The Weight of Leptin in Immunity. Nat. Rev. Immunol. 2004, 4, 371-379. [CrossRef] [PubMed]

49. Wauman, J.; Zabeau, L.; Tavernier, J. The Leptin Receptor Complex: Heavier than Expected? Front. Endocrinol. 2017, 8, 1-20. [CrossRef] [PubMed]

50. Haniu, M.; Arakawa, T.; Bures, E.J.; Young, Y.; Hui, J.O.; Rohde, M.F.; Welcher, A.A.; Horan, T. Human Leptin Receptor: Determination of Disulfide Structure and N- Glycosylation Sites of the Extracellular Domain. J. Biol. Chem. 1998, 273, 28691-28699. [CrossRef]

51. Kielar, D.; Clark, J.S.C.; Ciechanowicz, A.; Kurzawski, G.; Sulikowski, T.; Naruszewicz, M. Leptin Receptor Isoforms Expressed in Human Adipose Tissue. Metabolism 1998, 47, 844-847. [CrossRef]

52. Tsuchiya, T.; Shimizu, H.; Horie, T.; Mori, M. Expression of Leptin Receptor in Lung: Leptin as a Growth Factor. Eur. J. Pharmacol. 1999, 365, 273-279. [CrossRef]

53. Hahn, T.M.; Breininger, J.F.; Baskin, D.G.; Schwartz, M.W. Coexpression of Agrp and NPY in Fasting-Activated Hypothalamic Neurons. Nat. Neurosci. 1998, 1, 271-272. [CrossRef]

54. Vaisse, C.; Halaas, J.L.; Horvath, C.M.; Darnell, J.E.; Stoffel, M.; Friedman, J.M. Leptin Activation of Stat3 in the Hypothalamus of Wild-Type and Ob/Ob Mice but Not Db/Db Mice. Nat. Genet. 1996, 14, 95-97. [CrossRef] [PubMed]

55. Bjørbaek, C.; Elmquist, J.K.; Daniel Frantz, J.; Shoelson, S.E.; Flier, J.S. Identification of SOCS-3 as a Potential Mediator of Central Leptin Resistance Cytokine-like Signal Transduction by Stimulating the JAK-STAT Pathway via the Long Leptin Receptor Isoform. Mol. Cell 1998, 1, 619-625. [CrossRef]

56. Bjørbæk, C.; Buchholz, R.M.; Davis, S.M.; Bates, S.H.; Pierroz, D.D.; Gu, H.; Neel, B.G.; Myers, M.G.; Flier, J.S. Divergent Roles of SHP-2 in ERK Activation by Leptin Receptors. J. Biol. Chem. 2001, 276, 4747-4755. [CrossRef] [PubMed]

57. Kitamura, T. Forkhead Protein FoxO1 Mediates Agrp-Dependent Effects of Leptin on Food Intake. Nat Med. 2006, 12, 534-540. [CrossRef]

58. Cota, D.; Proulx, K.; Blake Smith, K.A.; Kozma, S.C.; Thomas, G.; Woods, S.C.; Seeley, R.J. Hypothalamic MTOR Signaling Regulates Food Intake. Science 2006, 312, 927-930. [CrossRef] [PubMed]

59. Minokoshi, Y.; Kim, Y.-B.; Peroni, O.D.; Fryer, L.G.D.; Müller, C.; Carling, D.; Kahn, B.B. Leptin Stimulates Fatty-Acid Oxidation by Activating AMP-Activated Protein Kinase. Nature 2002, 415, 339-343. [CrossRef]

60. Minokoshi, Y.; Alquier, T.; Furukawa, H.; Kim, Y.B.; Lee, A.; Xue, B.; Mu, J.; Foufelle, F.; Ferré, P.; Birnbaum, M.J.; et al. AMPKinase Regulates Food Intake by Responding to Hormonal and Nutrient Signals in the Hypothalamus. Nature 2004, 428, 569-574. [CrossRef]

61. Wauman, J.; Tavernier, J. Leptin Receptor Signaling: Pathways to Leptin Resistance. Front. Biosci. 2011, 16, 2771-2793. [CrossRef]

62. Kaszubska, W.; Falls, H.D.; Schaefer, V.G.; Haasch, D.; Frost, L.; Hessler, P.; Kroeger, P.E.; White, D.W.; Jirousek, M.R.; Trevillyan, J.M. Protein Tyrosine Phosphatase 1B Negatively Regulates Leptin Signaling in a Hypothalamic Cell Line. Mol. Cell. Endocrinol. 2002, 195, 109-118. [CrossRef]

63. Ouchi, N.; Parker, J.L.; Lugus, J.J.; Walsh, K. Adipokines in Inflammation and Metabolic Disease. Nat. Rev. Immunol. 2011, 11, 85. [CrossRef]

64. Santos-Alvarez, J.; Goberna, R.; Sá Nchez-Margalet, V. Human Leptin Stimulates Proliferation and Activation of Human Circulating Monocytes. Cell Immunol. 1999, 6-11. [CrossRef]

65. Paz-Filho, G.; Mastronardi, C.; Franco, C.B.; Wang, K.B.; Wong, M.-L.; Licinio, J. Leptin: Molecular Mechanisms, Systemic pro-Inflammatory Effects, and Clinical Implications. Arq. Bras. Endocrinol. Metabol. 2012, 56, 597-607. [CrossRef]

66. Tian, Z.; Sun, R.; Wei, H.; Gao, B. Impaired Natural Killer (NK) Cell Activity in Leptin Receptor Deficient Mice: Leptin as a Critical Regulator in NK Cell Development and Activation. Biochem. Biophys. Res. Commun. 2002, 298, 297-302. [CrossRef]

67. La Cava, A.; Alviggi, C.; Matarese, G. Unraveling the Multiple Roles of Leptin in Inflammation and Autoimmunity. J. Mol. Med. 2004, 4-11. [CrossRef]

68. Lord, G.M.; Matarese, G.; Howard, J.K.; Baker, R.J.; Bloom, S.R.; Lechler, R.I. Leptin Modulates the T-Cell Immune Response and Reverses Starvation-Induced Immunosuppression. Nature 1998, 394, 897-901. [CrossRef]

69. Bełtowski, J. Adiponectin and Resistin-New Hormones of White Adipose Tissue. Med Sci. Monitor. 2003, 9, RA55-RA61.

70. Steppan, C.M.; Wang, J.; Whiteman, E.L.; Birnbaum, M.J.; Lazar, M.A. Activation of SOCS-3 by Resistin. Mol. Cell. Biol. 2005, 25, 1569-1575. [CrossRef] [PubMed]

71. Degawa-Yamauchi, M.; Bovenkerk, J.E.; Juliar, B.E.; Watson, W.; Kerr, K.; Jones, R.; Zhu, Q.; Considine, R.V. Serum Resistin (FIZZ3) Protein Is Increased in Obese Humans. J. Clin. Endocrinol. Metab. 2003, 88, 5452-5455. [CrossRef] [PubMed]

72. Steppan, C.M.; Bailey, S.T.; Bhat, S.; Brown, E.J.; Banerjee, R.R.; Wright, C.M.; Patel, H.R.; Ahima, R.S.; Lazar, M.A. The Hormone Resistin Links Obesity to Diabetes. Nature 2001, 409, 307-312. [CrossRef] [PubMed]

73. Savage, D.B.; Sewter, C.P.; Klenk, E.S.; Segal, D.G.; Vidal-Puig, A.; Considine, R.V.; O'Rahilly, S. Resistin / Fizz3 Expression in Relation to Obesity and Peroxisome Proliferator-Activated Receptor- $\gamma$ Action in Humans. Diabetes 2001, 50, 2199-2202. [CrossRef] [PubMed]

74. Banerjee, R.R.; Lazar, M.A. Resistin: Molecular History and Prognosis. J. Mol. Med. 2003, 218-226. [CrossRef]

75. Bokarewa, M.; Nagaev, I.; Dahlberg, L.; Smith, U.; Tarkowski, A. Resistin, an Adipokine with Potent Proinflammatory Properties. J. Immunol. 2005, 174, 5789-5795. [CrossRef] 
76. Verma, S.; Li, S.H.; Wang, C.H.; Fedak, P.W.M.; Li, R.K.; Weisel, R.D.; Mickle, D.A.G. Resistin Promotes Endothelial Cell Activation: Further Evidence of Adipokine-Endothelial Interaction. Circulation 2003, 108, 736-740. [CrossRef]

77. Revollo, J.R.; Körner, A.; Mills, K.F.; Satoh, A.; Wang, T.; Garten, A.; Dasgupta, B.; Sasaki, Y.; Wolberger, C.; Townsend, R.R.; et al. Nampt/PBEF/Visfatin Regulates Insulin Secretion in $\beta$ Cells as a Systemic NAD Biosynthetic Enzyme. Cell Metab. 2007, 6, 363-375. [CrossRef] [PubMed]

78. Haider, D.G.; Schindler, K.; Schaller, G.; Prager, G.; Wolzt, M.; Ludvik, B. Increased Plasma Visfatin Concentrations in Morbidly Obese Subjects Are Reduced after Gastric Banding. J. Clin. Endocrinol. Metab. 2006, 91, 1578-1581. [CrossRef] [PubMed]

79. Cook, K.S.; Min, H.Y.; Johnson, D.; Chaplinsky, R.J.; Flier, J.S.; Hunt, C.R.; Spiegelman, B.M. Adipsin: A Circulating Serine Protease Homolog Secreted by Adipose Tissue and Sciatic Nerve. Science 1987, 237, 402-405. [CrossRef]

80. White, R.T.; Damm, D.; Hancock, N.; Rosen, B.S.; Lowell, B.B.; Usher, P.; Flier, J.S.; Spiegelman, B.M. Human Adipsin Is Identical to Complement Factor D and Is Expressed at High Levels in Adipose Tissue. J. Biol. Chem. 1992, 267, 9210-9213. [CrossRef]

81. Flier, J.S.; Cook, K.S.; Usher, P.; Spiegelman, B.M. Severely Impaired Adipsin Expression in Genetic and Acquired Obesity. Science 1987, 237, 405-408. [CrossRef] [PubMed]

82. Napolitano, A.; Lowell, B.B.; Damm, D.; Leibel, R.L.; Ravussin, E.; Jimerson, D.C.; Lesem, M.D.; Van Dyke, D.C.; Daly, P.A.; Chatis, P.; et al. Concentrations of Adipsin in Blood and Rates of Adipsin Secretion by Adipose Tissue in Humans with Normal, Elevated and Diminished Adipose Tissue Mass. Int. J. Obes. 1994, 18, 213-218.

83. Lo, J.C.; Ljubicic, S.; Leibiger, B.; Kern, M.; Leibiger, I.B.; Moede, T.; Kelly, M.E.; Chatterjee Bhowmick, D.; Murano, I.; Cohen, P.; et al. Adipsin is an Adipokine That Improves $\beta$ Cell Function in Diabetes. Cell 2014, 158, 41-53. [CrossRef]

84. Wentworth, J.M.; Zhang, J.G.; Bandala-Sanchez, E.; Naselli, G.; Liu, R.; Ritchie, M.; Smyth, G.K.; O’Brien, P.E.; Harrison, L.C. Interferon-Gamma Released from Omental Adipose Tissue of Insulin-Resistant Humans Alters Adipocyte Phenotype and Impairs Response to Insulin and Adiponectin Release. Int. J. Obes. 2017, 41, 1782-1789. [CrossRef] [PubMed]

85. Surendar, J.; Frohberger, S.J.; Karunakaran, I.; Schmitt, V.; Stamminger, W.; Neumann, A.-L.; Wilhelm, C.; Hoerauf, A.; Hübner, M.P. Adiponectin Limits IFN- $\gamma$ and IL-17 Producing CD4 T Cells in Obesity by Restraining Cell Intrinsic Glycolysis. Front. Immunol. 2019, 10, 2555. [CrossRef]

86. Rocha, V.Z.; Libby, P. Obesity, Inflammation, and Atherosclerosis. Nat. Rev. Cardiol. 2009, 6, 399-409. [CrossRef] [PubMed]

87. Pacifico, L.; Di Renzo, L.; Anania, C.; Osborn, J.F.; Ippoliti, F.; Schiavo, E.; Chiesa, C. Increased T-Helper Interferon- $\gamma$-Secreting Cells in Obese Children. Eur. J. Endocrinol. 2006, 154, 691-697. [CrossRef] [PubMed]

88. Thiel, V.; Weber, F. Interferon and Cytokine Responses to SARS-Coronavirus Infection. Cytokine Growth Factor Rev. 2008, 121-132. [CrossRef]

89. Kern, P.A.; Saghizadeh, M.; Ong, J.M.; Bosch, R.J.; Deem, R.; Simsolo, R.B. The Expression of Tumor Necrosis Factor in Human Adipose Tissue: Regulation by Obesity, Weight Loss, and Relationship to Lipoprotein Lipase. J. Clin. Invest. 1995, 95, 2111-2119. [CrossRef] [PubMed]

90. Hotamisligil, G.S.; Budavari, A.; Murray, D.; Spiegelman, B.M. Reduced Tyrosine Kinase Activity of the Insulin Receptor in Obesity- Diabetes. Central Role of Tumor Necrosis Factor- $\alpha$. J. Clin. Invest. 1994, 94, 1543-1549. [CrossRef]

91. Fain, J.N.; Madan, A.K.; Hiler, M.L.; Cheema, P.; Bahouth, S.W. Comparison of the Release of Adipokines by Adipose Tissue, Adipose Tissue Matrix, and Adipocytes from Visceral and Subcutaneous Abdominal Adipose Tissues of Obese Humans. Endocrinology 2004, 145, 2273-2282. [CrossRef]

92. Fried, S.K.; Bunkin, D.A.; Greenberg, A.S. Omental and Subcutaneous Adipose Tissues of Obese Subjects Release Interleukin-6: Depot Difference and Regulation by Glucocorticoid ${ }^{1}$. J. Clin. Endocrinol. Metab. 1998, 83, 847-850. [CrossRef]

93. Senn, J.J.; Klover, P.J.; Nowak, I.A.; Zimmers, T.A.; Koniaris, L.G.; Furlanetto, R.W.; Mooney, R.A. Suppressor of Cytokine Signaling-3 (SOCS-3), a Potential Mediator of Interleukin-6-Dependent Insulin Resistance in Hepatocytes. J. Biol. Chem. 2003, 278, 13740-13746. [CrossRef]

94. Esposito, K.; Pontillo, A.; Ciotola, M.; Di Palo, C.; Grella, E.; Nicoletti, G.; Giugliano, D. Weight Loss Reduces Interleukin-18 Levels in Obese Women. J. Clin. Endocrinol. Metab. 2002, 87, 3864-3866. [CrossRef]

95. Tan, H.W.; Liu, X.; Bi, X.P.; Xing, S.S.; Li, L.; Gong, H.P.; Zhong, M.; Wang, Z.H.; Zhang, Y.; Zhang, W. IL-18 Overexpression Promotes Vascular Inflammation and Remodeling in a Rat Model of Metabolic Syndrome. Atherosclerosis 2010, 208, 350-357. [CrossRef] [PubMed]

96. Yang, Q.; Graham, T.E.; Mody, N.; Preitner, F.; Peroni, O.D.; Zabolotny, J.M.; Kotani, K.; Quadro, L.; Kahn, B.B. Serum Retinol Binding Protein 4 Contributes to Insulin Resistance in Obesity and Type 2 Diabetes. Nature 2005, 436, 356-362. [CrossRef] [PubMed]

97. Graham, T.E.; Yang, Q.; Blüher, M.; Hammarstedt, A.; Ciaraldi, T.P.; Henry, R.R.; Wason, C.J.; Oberbach, A.; Jansson, P.-A.; Smith, U.; et al. Retinol-Binding Protein 4 and Insulin Resistance in Lean, Obese, and Diabetic Subjects. N. Engl. J. Med. 2006, 354, 2552-2563. [CrossRef] [PubMed]

98. Broch, M.; Ramírez, R.; Auguet, M.T.; Alcaide, M.J.; Aguilar, C.; Garcia-España, A.; Richart, C.; Xxiii, C.; Guasch, M. Macrophages Are Novel Sites of Expression and Regulation of Retinol Binding Protein-4 (RBP4). Physiol. Res. 2010, 59, 299-303. [CrossRef]

99. Tabata, M.; Kadomatsu, T.; Fukuhara, S.; Miyata, K.; Ito, Y.; Endo, M.; Urano, T.; Zhu, H.J.; Tsukano, H.; Tazume, H.; et al. Angiopoietin-like Protein 2 Promotes Chronic Adipose Tissue Inflammation and Obesity-Related Systemic Insulin Resistance. Cell Metab. 2009, 10, 178-188. [CrossRef] 
100. Wang, Y.; Lam, K.S.L.; Kraegen, E.W.; Sweeney, G.; Zhang, J.; Tso, A.W.; Chow, W.-S.; Wat, N.M.; Xu, J.Y.; Hoo, R.L.; et al. Lipocalin-2 Is an Inflammatory Marker Closely Associated with Obesity, Insulin Resistance, and Hyperglycemia in Humans. Clin. Chem. 2007, 53, 34-41. [CrossRef]

101. Kanda, H.; Tateya, S.; Tamori, Y.; Kotani, K.; Hiasa, K.I.; Kitazawa, R.; Kitazawa, S.; Miyachi, H.; Maeda, S.; Egashira, K.; et al. MCP-1 Contributes to Macrophage Infiltration into Adipose Tissue, Insulin Resistance, and Hepatic Steatosis in Obesity. J. Clin. Invest. 2006, 116, 1494-1505. [CrossRef]

102. Chavey, C.; Lazennec, G.; Lagarrigue, S.; Clapé, C.; Iankova, I.; Teyssier, J.; Annicotte, J.S.; Schmidt, J.; Mataki, C.; Yamamoto, H.; et al. CXC Ligand 5 Is an Adipose-Tissue Derived Factor That Links Obesity to Insulin Resistance. Cell Metab. 2009, 9, 339-349. [CrossRef]

103. Sartipy, P.; Loskutoff, D.J. Monocyte Chemoattractant Protein 1 in Obesity and Insulin Resistance. Proc. Natl. Acad. Sci. USA 2003, 100, 7265-7270. [CrossRef]

104. Hu, E.; Liang, P.; Spiegelman, B.M. AdipoQ Is a Novel Adipose-Specific Gene Dysregulated in Obesity. J. Biol. Chem. 1996, 271, 10697-10703. [CrossRef]

105. Steffes, M.W.; Gross, M.D.; Schreiner, P.J.; Yu, X.; Hilner, J.E.; Gingerich, R.; Jacobs, D.R. Serum Adiponectin in Young AdultsInteractions with Central Adiposity, Circulating Levels of Glucose, and Insulin Resistance: The CARDIA Study. Ann. Epidemiol. 2004, 14, 492-498. [CrossRef]

106. Ouchi, N.; Kihara, S.; Funahashi, T.; Matsuzawa, Y.; Walsh, K. Obesity, Adiponectin and Vascular Inflammatory Disease. Curr. Opin. Lipidol. 2003, 14, 561-566. [CrossRef]

107. Pischon, T.; Hotamisligil, G.S.; Rimm, E.B. Adiponectin: Stability in Plasma over 36 Hours and within-Person Variation over 1 Year. Clin. Chem. 2003, 49, 650-652. [CrossRef]

108. Waki, H.; Yamauchi, T.; Kamon, J.; Ito, Y.; Uchida, S.; Kita, S.; Hara, K.; Hada, Y.; Vasseur, F.; Froguel, P.; et al. Impaired Multimerization of Human Adiponectin Mutants Associated with Diabetes. Molecular Structure and Multimer Formation of Adiponectin. J. Biol. Chem. 2003, 278, 40352-40363. [CrossRef]

109. Hara, K.; Horikoshi, M.; Yamauchi, T.; Yago, H.; Miyazaki, O.; Ebinuma, H.; Imai, Y.; Nagai, R.; Kadowaki, T. Measurement of the High-Molecular Weight Form of Adiponectin in Plasma Is Useful for the Prediction of Insulin Resistance and Metabolic Syndrome. Diabetes Care 2006, 29, 1357-1362. [CrossRef]

110. Yamauchi, T.; Kamon, J.; Ito, Y.; Tsuchida, A.; Yokomizo, T.; Kita, S.; Sugiyama, T.; Miyagishi, M.; Hara, K.; Tsunoda, M.; et al. Cloning of Adiponectin Receptors That Mediate Antidiabetic Metabolic Effects. Nature 2003, 423, 762-769. [CrossRef] [PubMed]

111. Yamauchi, T.; Kamon, J.; Minokoshi, Y.; Ito, Y.; Waki, H.; Uchida, S.; Yamashita, S.; Noda, M.; Kita, S.; Ueki, K.; et al. Adiponectin Stimulates Glucose Utilization and Fatty-Acid Oxidation by Activating AMP-Activated Protein Kinase. Nat. Med. 2002, 8 , 1288-1295. [CrossRef] [PubMed]

112. Turer, A.T.; Khera, A.; Ayers, C.R.; Turer, C.B.; Grundy, S.M.; Vega, G.L.; Scherer, P.E. Adipose Tissue Mass and Location Affect Circulating Adiponectin Levels. Diabetologia 2011, 54, 2515-2524. [CrossRef]

113. Wijesekara, N.; Krishnamurthy, M.; Bhattacharjee, A.; Suhail, A.; Sweeney, G.; Wheeler, M.B. Adiponectin-Induced ERK and Akt Phosphorylation Protects against Pancreatic Beta Cell Apoptosis and Increases Insulin Gene Expression and Secretion. J. Biol. Chem. 2010, 285, 33623-33631. [CrossRef] [PubMed]

114. Berg, A.H.; Combs, T.P.; Du, X.; Brownlee, M.; Scherer, P.E. The Adipocyte-Secreted Protein Acrp30 Enhances Hepatic Insulin Action. Nat. Med. 2001, 7, 947-953. [CrossRef]

115. Schäffler, A.; Schölmerich, J.; Büchler, C. Mechanisms of Disease: Adipocytokines and Visceral Adipose Tissue-Emerging Role in Nonalcoholic Fatty Liver Disease. Nat. Clin. Pract. Gastroenterol. Hepatol. 2005, 273-280. [CrossRef]

116. Kelesidis, I.; Kelesidis, T.; Mantzoros, C.S. Adiponectin and Cancer: A Systematic Review. Br. J. Cancer 2006, 1221-1225. [CrossRef] [PubMed]

117. Pischon, T.; Girman, C.J.; Hotamisligil, G.S.; Rifai, N.; Hu, F.B.; Rimm, E.B. Plasma Adiponectin Levels and Risk of Myocardial Infarction in Men. J. Am. Med. Assoc. 2004, 291, 1730-1737. [CrossRef] [PubMed]

118. Thyagarajan, B.; Jacobs, D.R.; Smith, L.J.; Kalhan, R.; Gross, M.D.; Sood, A. Serum Adiponectin Is Positively Associated with Lung Function in Young Adults, Independent of Obesity: The CARDIA Study. Respir. Res. 2010, 11. [CrossRef] [PubMed]

119. Wulster-Radcliffe, M.C.; Ajuwon, K.M.; Wang, J.; Christian, J.A.; Spurlock, M.E. Adiponectin Differentially Regulates Cytokines in Porcine Macrophages. Biochem. Biophys. Res. Commun. 2004, 316, 924-929. [CrossRef]

120. Ouchi, N.; Kihara, S.; Arita, Y.; Maeda, K.; Kuriyama, H.; Okamoto, Y.; Hotta, K.; Nishida, M.; Takahashi, M.; Nakamura, T.; et al Novel Modulator for Endothelial Adhesion Molecules: Adipocyte-Derived Plasma Protein Adiponectin. Circulation 1999, 100, 2473-2476. [CrossRef] [PubMed]

121. Ryo, M.; Nakamura, T.; Kihara, S.; Kumada, M.; Shibazaki, S.; Takahashi, M.; Nagai, M.; Matsuzawa, Y.; Funahashi, T. Adiponectin as a Biomarker of the Metabolic Syndrome. Circ. J. 2004, 68, 975-981. [CrossRef]

122. Hosogai, N.; Fukuhara, A.; Oshima, K.; Miyata, Y.; Tanaka, S.; Segawa, K.; Furukawa, S.; Tochino, Y.; Komuro, R.; Matsuda, M.; et al. Adipose Tissue Hypoxia in Obesity and Its Impact on Adipocytokine Dysregulation. Diabetes 2007, 56, 901-911. [CrossRef]

123. Kumada, M.; Kihara, S.; Ouchi, N.; Kobayashi, H.; Okamoto, Y.; Ohashi, K.; Maeda, K.; Nagaretani, H.; Kishida, K.; Maeda, N.; et al. Adiponectin Specifically Increased Tissue Inhibitor of Metalloproteinase-1 Through Interleukin-10 Expression in Human Macrophages. Circulation 2004, 109, 2046-2049. [CrossRef] 
124. Ohashi, K.; Parker, J.L.; Ouchi, N.; Higuchi, A.; Vita, J.A.; Gokce, N.; Pedersen, A.A.; Kalthoff, C.; Tullin, S.; Sams, A.; et al. Adiponectin Promotes Macrophage Polarization toward an Anti-Inflammatory Phenotype. J. Biol. Chem. 2010, 285, 6153-6160. [CrossRef]

125. Ouchi, N.; Higuchi, A.; Ohashi, K.; Oshima, Y.; Gokce, N.; Shibata, R.; Akasaki, Y.; Shimono, A.; Walsh, K. Sfrp5 Is an AntiInflammatory Adipokine That Modulates Metabolic Dysfunction in Obesity. Science 2010, 329, 454-457. [CrossRef] [PubMed]

126. Hu, Z.; Deng, H.; Qu, H. Plasma SFRP5 Levels Are Decreased in Chinese Subjects with Obesity and Type 2 Diabetes and Negatively Correlated with Parameters of Insulin Resistance. Diabetes Res. Clin. Pract. 2013, 99, 391-395. [CrossRef]

127. Iwashima, Y.; Katsuya, T.; Ishikawa, K.; Ouchi, N.; Ohishi, M.; Sugimoto, K.; Fu, Y.; Motone, M.; Yamamoto, K.; Matsuo, A.; et al. Hypoadiponectinemia Is an Independent Risk Factor for Hypertension. Hypertension 2004, 43, 1318-1323. [CrossRef] [PubMed]

128. Hotamisligil, G.S.; Shargill, N.S.; Spiegelman, B.M. Adipose Expression of Tumor Necrosis Factor- $\alpha$ : Direct Role in Obesity-Linked Insulin Resistance. Science 1993, 259, 87-91. [CrossRef] [PubMed]

129. Nilsson, C.; Raun, K.; Yan, F.F.; Larsen, M.O.; Tang-Christensen, M. Laboratory Animals as Surrogate Models of Human Obesity. Acta Pharmacol. Sin. 2012, 33, 173-181. [CrossRef]

130. Ingalls, A.M.; Dickie, M.M.; Shell, G.D. Obese, a New Mutation in the House Mouse. J. Hered. 1950, 41, 317-318. [CrossRef] [PubMed]

131. Frederich, R.C.; Lollmann, B.; Hamann, A.; Napolitano-Rosen, A.; Kahn, B.B.; Lowell, B.B.; Flier, J.S. Expression of Ob MRNA and Its Encoded Protein in Rodents. Impact of Nutrition and Obesity. J. Clin. Invest. 1995, 96, 1658-1663. [CrossRef]

132. Herberg, L.; Coleman, D.L. Laboratory Animals Exhibiting Obesity and Diabetes Syndromes. Metabolism 1977, $26,59-99$. [CrossRef]

133. Hummel, K.P.; Dickie, M.M.; Coleman, D.L. Diabetes, a New Mutafton in the Mouse. Science 1966, 153, 1127-1128. [CrossRef] [PubMed]

134. Fricker, L.D.; Leiter, E.H. Peptides, Enzymes and Obesity: New Insights from a "dead" Enzyme. Trends Biochem. Sci. 1999, 390-393. [CrossRef]

135. Zucker, T.F.; Zucker, L.M. Hereditary Obesity in the Rat Associated with High Serum Fat and Cholesterol. Proc. Soc. Exp. Biol. Med. 1962, 110, 165-171. [CrossRef]

136. Farooqi, I.S.; Jebb, S.A.; Langmack, G.; Lawrence, E.; Cheetham, C.H.; Prentice, A.M.; Hughes, I.A.; McCamish, M.A.; O’Rahilly, S. Effects of Recombinant Leptin Therapy in a Child with Congenital Leptin Deficiency. N. Engl. J. Med. 1999, 341, 879-884. [CrossRef]

137. Myers, M.G.; Cowley, M.A.; Münzberg, H. Mechanisms of Leptin Action and Leptin Resistance. Annu. Rev. Physiol. 2008, 70, 537-556. [CrossRef]

138. Myers, M.G.; Leibel, R.L.; Seeley, R.J.; Schwartz, M.W. Obesity and Leptin Resistance: Distinguishing Cause from Effect. Trends Endocrinol. Metab. 2010, 643-651. [CrossRef] [PubMed]

139. Rothwell, N.J.; Stock, M.J. The Cafetaria Diet as a Tool for Studies of Thermogenesis. J. Nutr. 1988, 925-928. [CrossRef]

140. Levin, B.E.; Hogan, S.; Sullivan, A.C. Initiation and Perpetuation of Obesity and Obesity Resistance in Rats. Am. J. Physiol. Regul. Integr. Comp. Physiol. 1989, 256. [CrossRef] [PubMed]

141. Seth, A.; Stemple, D.L.; Barroso, I. The Emerging Use of Zebrafish to Model Metabolic Disease. DMM Dis. Models Mech. 2013, 1080-1088. [CrossRef]

142. Zang, L.; Maddison, L.A.; Chen, W. Zebrafish as a Model for Obesity and Diabetes. Front. Cell Dev. Biol. 2018, 6, 1-13. [CrossRef] [PubMed]

143. Mestas, J.; Hughes, C.C.W. Of Mice and Not Men: Differences between Mouse and Human Immunology. J. Immunol. 2004, 172, 2731-2738. [CrossRef]

144. Greek, R.; Menache, A. Systematic Reviews of Animal Models: Methodology versus Epistemology. Int. J. Med. Sci. 2013, 10, 206-221. [CrossRef]

145. van der Worp, H.B.; Howells, D.W.; Sena, E.S.; Porritt, M.J.; Rewell, S.; O'Collins, V.; Macleod, M.R. Can Animal Models of Disease Reliably Inform Human Studies? PLoS Med. 2010, 7, e1000245. [CrossRef]

146. Bahmad, H.F.; Daouk, R.; Azar, J.; Sapudom, J.; Teo, J.C.M.; Abou-Kheir, W.; Al-Sayegh, M. Modeling Adipogenesis: Current and Future Perspective. Cells 2020, 9, 2326. [CrossRef] [PubMed]

147. Li, X.; Easley, C.J. Microfluidic Systems for Studying Dynamic Function of Adipocytes and Adipose Tissue. Anal. Bioanal. Chem. 2018, 410, 791-800. [CrossRef]

148. Volz, A.C.; Omengo, B.; Gehrke, S.; Kluger, P.J. Comparing the Use of Differentiated Adipose-Derived Stem Cells and Mature Adipocytes to Model Adipose Tissue in Vitro. Differentiation 2019, 110, 19-28. [CrossRef] [PubMed]

149. Marx, U.; Akabane, T.; Andersson, T.B.; Baker, E.; Beilmann, M.; Beken, S.; Brendler-Schwaab, S.; Cirit, M.; David, R.; Dehne, E.M.; et al. Biology-Inspired Microphysiological Systems to Advance Patient Benefit and Animal Welfare in Drug Development. ALTEX 2020, 37, 364-394. [CrossRef]

150. Rogal, J.; Zbinden, A.; Schenke-Layland, K.; Loskill, P. Stem-Cell Based Organ-on-a-Chip Models for Diabetes Research. Adv. Drug Deliv. Rev. 2019, 140, 101-128. [CrossRef]

151. Klingelhutz, A.J.; Gourronc, F.A.; Chaly, A.; Wadkins, D.A.; Burand, A.J.; Markan, K.R.; Idiga, S.O.; Wu, M.; Potthoff, M.J.; Ankrum, J.A. Scaffold-Free Generation of Uniform Adipose Spheroids for Metabolism Research and Drug Discovery. Sci. Rep. 2018, 8, 1-12. [CrossRef] 
152. Taylor, J.; Sellin, J.; Kuerschner, L.; Krähl, L.; Majlesain, Y.; Förster, I.; Thiele, C.; Weighardt, H.; Weber, E. Generation of Immune Cell Containing Adipose Organoids for in Vitro Analysis of Immune Metabolism. Sci. Rep. 2020, 10, 1-14. [CrossRef]

153. Muller, S.; Ader, I.; Creff, J.; Leménager, H.; Achard, P.; Casteilla, L.; Sensebé, L.; Carrière, A.; Deschaseaux, F. Human Adipose Stromal-Vascular Fraction Self-Organizes to Form Vascularized Adipose Tissue in 3D Cultures. Sci. Rep. 2019, 9, 1-10. [CrossRef]

154. Abbott, R.D.; Wang, R.Y.; Reagan, M.R.; Chen, Y.; Borowsky, F.E.; Zieba, A.; Marra, K.G.; Rubin, J.P.; Ghobrial, I.M.; Kaplan, D.L. The Use of Silk as a Scaffold for Mature, Sustainable Unilocular Adipose 3D Tissue Engineered Systems. Adv. Healthc. Mater. 2016, 5, 1667-1677. [CrossRef] [PubMed]

155. Abbott, R.D.; Kimmerling, E.P.; Cairns, D.M.; Kaplan, D.L. Silk as a Biomaterial to Support Long-Term Three-Dimensional Tissue Cultures. ACS Appl. Mater. Interfaces 2016, 21861-21868. [CrossRef] [PubMed]

156. Huber, B.; Borchers, K.; Tovar, G.E.M.; Kluger, P.J. Methacrylated Gelatin and Mature Adipocytes Are Promising Components for Adipose Tissue Engineering. J. Biomater. Appl. 2016, 30, 699-710. [CrossRef] [PubMed]

157. Louis, F.; Kitano, S.; Mano, J.F.; Matsusaki, M. 3D Collagen Microfibers Stimulate the Functionality of Preadipocytes and Maintain the Phenotype of Mature Adipocytes for Long Term Cultures. Acta Biomater. 2019, 84, 194-207. [CrossRef]

158. Abbott, R.D.; Borowsky, F.E.; Alonzo, C.A.; Zieba, A.; Georgakoudi, I.; Kaplan, D.L. Variability in Responses Observed in Human White Adipose Tissue Models. J. Tissue Eng. Regen. Med. 2018, 12, 840-847. [CrossRef] [PubMed]

159. Lau, F.H.; Vogel, K.; Luckett, J.P.; Hunt, M.; Meyer, A.; Rogers, C.L.; Tessler, O.; Dupin, C.L.; St. Hilaire, H.; Islam, K.N.; et al. Sandwiched White Adipose Tissue: A Microphysiological System of Primary Human Adipose Tissue. Tissue Eng. Part C Methods 2018, 24, 135-145. [CrossRef]

160. Harms, M.J.; Li, Q.; Lee, S.; Zhang, C.; Kull, B.; Hallen, S.; Thorell, A.; Alexandersson, I.; Hagberg, C.E.; Peng, X.R.; et al. Mature Human White Adipocytes Cultured under Membranes Maintain Identity, Function, and Can Transdifferentiate into Brown-like Adipocytes. Cell Rep. 2019, 27, 213-225.e5. [CrossRef] [PubMed]

161. McCarthy, M.; Brown, T.; Alarcon, A.; Williams, C.; Wu, X.; Abbott, R.D.; Gimble, J.; Frazier, T. Fat-On-A-Chip Models for Research and Discovery in Obesity and Its Metabolic Comorbidities. Tissue Eng. Part B Rev. 2020, 26, 586-595. [CrossRef]

162. Godwin, L.A.; Brooks, J.C.; Hoepfner, L.D.; Wanders, D.; Judd, R.L.; Easley, C.J. A Microfluidic Interface for the Culture and Sampling of Adiponectin from Primary Adipocytes. Analyst 2015, 140, 1019-1025. [CrossRef]

163. Li, X.; Hu, J.; Easley, C.J. Automated Microfluidic Droplet Sampling with Integrated, Mix-and-Read Immunoassays to Resolve Endocrine Tissue Secretion Dynamics. Lab Chip 2018, 18, 2926-2935. [CrossRef]

164. Hu, J.; Li, X.; Judd, R.L.; Easley, C.J. Rapid Lipolytic Oscillations in: Ex Vivo Adipose Tissue Explants Revealed through Microfluidic Droplet Sampling at High Temporal Resolution. Lab Chip 2020, 20, 1503-1512. [CrossRef]

165. Zhu, J.; He, J.; Verano, M.; Brimmo, A.T.; Glia, A.; Qasaimeh, M.A.; Chen, P.; Aleman, J.O.; Chen, W. An Integrated AdiposeTissue-on-Chip Nanoplasmonic Biosensing Platform for Investigating Obesity-Associated Inflammation. Lab Chip 2018, 18, 3550-3560. [CrossRef]

166. Liu, Y.; Kongsuphol, P.; Chiam, S.Y.; Zhang, Q.X.; Gourikutty, S.B.N.; Saha, S.; Biswas, S.K.; Ramadan, Q. Adipose-on-a-Chip: A Dynamic Microphysiological in Vitro Model of the Human Adipose for Immune-Metabolic Analysis in Type II Diabetes. Lab Chip 2019, 19, 241-253. [CrossRef]

167. Rogal, J.; Binder, C.; Kromidas, E.; Roosz, J.; Probst, C.; Schneider, S.; Schenke-Layland, K.; Loskill, P. WAT-on-a-Chip Integrating Human Mature White Adipocytes for Mechanistic Research and Pharmaceutical Applications. Sci. Rep. 2020, 10, 1-12. [CrossRef]

168. Rogal, J.; Probst, C.; Loskill, P. Integration Concepts for Multi-Organ Chips: How to Maintain Flexibility?! Futur. Sci. OA 2017, 3. [CrossRef]

169. Frey, O.; Misun, P.M.; Fluri, D.A.; Hengstler, J.G.; Hierlemann, A. Reconfigurable Microfluidic Hanging Drop Network for Multi-Tissue Interaction and Analysis. Nat. Commun. 2014, 5. [CrossRef]

170. Edington, C.D.; Chen, W.L.K.; Geishecker, E.; Kassis, T.; Soenksen, L.R.; Bhushan, B.M.; Freake, D.; Kirschner, J.; Maass, C.; Tsamandouras, N.; et al. Interconnected Microphysiological Systems for Quantitative Biology and Pharmacology Studies. Sci. Rep. 2018, 8, 1-18. [CrossRef] [PubMed]

171. Deinhardt-Emmer, S.; Rennert, K.; Schicke, E.; Cseresnyés, Z.; Windolph, M.; Nietzsche, S.; Heller, R.; Siwczak, F.; Haupt, K.F.; Carlstedt, S.; et al. Co-Infection with Staphylococcus Aureus after Primary Influenza Virus Infection Leads to Damage of the Endothelium in a Human Alveolus-on-a-Chip Model. Biofabrication 2020, 12, 025012. [CrossRef] [PubMed]

172. Brown, P.D.; Lerner, S.A. Community-Acquired Pneumonia. Lancet 1998, 1295-1302. [CrossRef]

173. Park, J.; Ahmadi, S.F.; Streja, E.; Molnar, M.Z.; Flegal, K.M.; Gillen, D.; Kovesdy, C.P.; Kalantar-Zadeh, K. Obesity Paradox in End-Stage Kidney Disease Patients. Prog. Cardiovasc. Dis. 2014, 56, 415-425. [CrossRef] [PubMed]

174. Corrales-Medina, V.F.; Valayam, J.; Serpa, J.A.; Rueda, A.M.; Musher, D.M. The Obesity Paradox in Community-Acquired Bacterial Pneumonia. Int. J. Infect. Dis. 2011, 15, e54-e57. [CrossRef]

175. Singanayagam, A.; Singanayagam, A.; Chalmers, J.D. Obesity Is Associated with Improved Survival in Community-Acquired Pneumonia. Eur. Respir. J. 2013, 42, 180-187. [CrossRef]

176. Chen, J.; Wang, J.; Jiang, H.; Li, M.C.; He, S.Y.; Li, X.P.; Shen, D. Lower Long-Term Mortality in Obese Patients with CommunityAcquired Pneumonia: Possible Role of CRP. Clinics 2019, 74, 1-6. [CrossRef] [PubMed]

177. Braun, N.; Hoess, C.; Kutz, A.; Christ-Crain, M.; Thomann, R.; Henzen, C.; Zimmerli, W.; Mueller, B.; Schuetz, P. Obesity Paradox in Patients with Community-Acquired Pneumonia: Is Inflammation the Missing Link? Nutrition 2017, 33, 304-310. [CrossRef] [PubMed] 
178. Baik, I.; Curhan, G.C.; Rimm, E.B.; Bendich, A.; Willett, W.C.; Fawzi, W.W. A Prospective Study of Age and Lifestyle Factors in Relation to Community-Acquired Pneumonia in US Men and Women. Arch. Intern. Med. 2000, 160, 3082-3088. [CrossRef] [PubMed]

179. Hsu, A.; Aronoff, D.M.; Phipps, J.; Goel, D.; Mancuso, P. Leptin Improves Pulmonary Bacterial Clearance and Survival in Ob/Ob Mice during Pneumococcal Pneumonia. Clin. Exp. Immunol. 2007, 150, 332-339. [CrossRef] [PubMed]

180. Mancuso, P.; Gottschalk, A.; Phare, S.M.; Peters-Golden, M.; Lukacs, N.W.; Huffnagle, G.B. Leptin-Deficient Mice Exhibit Impaired Host Defense in Gram-Negative Pneumonia. J. Immunol. 2002, 168, 4018-4024. [CrossRef]

181. Mancuso, P.; O'brien, E.; Prano, J.; Goel, D.; Aronoff, D.M. No Impairment in Host Defense against Streptococcus Pneumoniae in Obese CPEfat/Fat Mice. PLoS ONE 2014, 9, 3-9. [CrossRef] [PubMed]

182. Ubags, N.D.J.; Burg, E.; Antkowiak, M.; Wallace, A.M.; Dilli, E.; Bement, J.; Wargo, M.J.; Poynter, M.E.; Wouters, E.F.M.; Suratt, B.T. A Comparative Study of Lung Host Defense in Murine Obesity Models: Insights into Neutrophil Function. Am. J. Respir. Cell Mol. Biol. 2016, 55, 188-200. [CrossRef]

183. Ahmed, Q.A.A.; Niederman, M.S. Respiratory Infection in the Chronically Critically Ill Patient: Ventilator-Associated Pneumonia and Tracheobronchitis. Clin. Chest Med. 2001, 22, 71-85. [CrossRef]

184. Wang, F.; Zuo, Z.; Chen, K.; Fang, J.; Cui, H.; Shu, G.; Zhou, Y.; Chen, Z.; Huang, C.; Liu, W. Histopathological Changes Caused by Inflammation and Oxidative Stress in Diet-Induced-Obese Mouse Following Experimental Lung Injury. Sci. Rep. 2018, 8, 1-11. [CrossRef]

185. Wan, T.; Yuan, G.; Ren, Y.; Zuo, Z.; Wang, Z.; Jia, Y.; Cui, H.; Peng, X.; Fang, J.; Deng, J.; et al. Diet-Induced Obese Mice Exhibit Altered Immune Responses to Acute Lung Injury Induced by Escherichia Coli. Obesity 2016, 24, 2101-2110. [CrossRef]

186. Wang, F.; Zuo, Z.; Yang, Z.; Chen, K.; Fang, J.; Cui, H.; Shu, G.; Zhou, Y.; Geng, Y.; Ouyang, P. Delayed Pulmonary Apoptosis of Diet-Induced Obesity Mice Following Escherichia Coli Infection through the Mitochondrial Apoptotic Pathway. Oxid. Med. Cell. Longev. 2019, 2019. [CrossRef]

187. Ubags, N.D.J.; Stapleton, R.D.; Vernooy, J.H.J.; Burg, E.; Bement, J.; Hayes, C.M.; Ventrone, S.; Zabeau, L.; Tavernier, J.; Poynter, M.E.; et al. Hyperleptinemia Is Associated with Impaired Pulmonary Host Defense. JCI Insight 2016, 1, 1-13. [CrossRef] [PubMed]

188. Després, J.P. Excess Visceral Adipose Tissue/Ectopic Fat: The Missing Link in the Obesity Paradox? J. Am. Coll. Cardiol. 2011, 57, 1887-1889. [CrossRef] [PubMed]

189. Girard, M.P.; Tam, J.S.; Assossou, O.M.; Kieny, M.P. The 2009 A (H1N1) Influenza Virus Pandemic: A Review. Vaccine 2010, 28, 4895-4902. [CrossRef]

190. Hinshaw, V.S.; Webster, R.G.; Turnert, B. Novel Influenza A Viruses Isolated from Canadian Feral Ducks: Including Strains Antigenically Related to Swine Influenza (HswlN1) Viruses. J. Gen. Virol. 1985, 288, 115-127. [CrossRef] [PubMed]

191. Brown, I.H. The Epidemiology and Evolution of Influenza Viruses in Pigs. In Veterinary Microbiology; Elsevier: Amsterdam, The Netherlands, 2000; Volume 74, pp. 29-46. [CrossRef]

192. Jain, S.; Kamimoto, L.; Bramley, A.M.; Schmitz, A.M.; Benoit, S.R.; Louie, J.; Sugerman, D.E.; Druckenmiller, J.K.; Ritger, K.A.; Chugh, R.; et al. Hospitalized Patients with 2009 H1N1 Influenza in the United States, April-June 2009. N. Engl. J. Med. 2009, 361, 1935-1944. [CrossRef]

193. Fezeu, L.; Julia, C.; Henegar, A.; Bitu, J.; Hu, F.B.; Grobbee, D.E.; Kengne, A.P.; Hercberg, S.; Czernichow, S. Obesity Is Associated with Higher Risk of Intensive Care Unit Admission and Death in Influenza A (H1N1) Patients: A Systematic Review and Meta-Analysis. Obes. Rev. 2011, 12, 653-659. [CrossRef]

194. Morgan, O.W.; Bramley, A.; Fowlkes, A.; Freedman, D.S.; Taylor, T.H.; Gargiullo, P.; Belay, B.; Jain, S.; Cox, C.; Kamimoto, L.; et al. Morbid Obesity as a Risk Factor for Hospitalization and Death Due to 2009 Pandemic Influenza A(H1N1) Disease. PLoS ONE 2010, 5, 1-6. [CrossRef]

195. Braun, E.S.; Crawford, F.W.; Desai, M.M.; Meek, J.; Kirley, P.D.; Miller, L.; Anderson, E.J.; Oni, O.; Ryan, P.; Lynfield, R.; et al. Obesity Not Associated with Severity among Hospitalized Adults with Seasonal Influenza Virus Infection. Infection 2015, 43. [CrossRef] [PubMed]

196. Easterbrook, J.D.; Dunfee, R.L.; Schwartzman, L.M.; Jagger, B.W.; Sandouk, A.; Kash, J.C.; Memoli, M.J.; Taubenberger, J.K. Obese Mice Have Increased Morbidity and Mortality Compared to Non-Obese Mice during Infection with the 2009 Pandemic H1N1 Influenza Virus. Influenza Other Respi. Viruses 2011, 5, 418-425. [CrossRef]

197. Zhang, A.J.X.; To, K.K.W.; Li, C.; Lau, C.C.Y.; Poon, V.K.M.; Chan, C.C.S.; Zheng, B.J.; Hung, I.F.N.; Lam, K.S.L.; Xu, A.; et al. Leptin Mediates the Pathogenesis of Severe 2009 Pandemic Influenza A(H1N1) Infection Associated with Cytokine Dysregulation in Mice with Diet-Induced Obesity. J. Infect. Dis. 2013, 207, 1270-1280. [CrossRef]

198. Milner, J.J.; Rebeles, J.; Dhungana, S.; Stewart, D.A.; Sumner, S.C.J.; Meyers, M.H.; Mancuso, P.; Beck, M.A. Obesity Increases Mortality and Modulates the Lung Metabolome during Pandemic H1N1 Influenza Virus Infection in Mice. J. Immunol. 2015, 194, 4846-4859. [CrossRef]

199. Radigan, K.A.; Morales-Nebreda, L.; Soberanes, S.; Nicholson, T.; Nigdelioglu, R.; Cho, T.; Chi, M.; Hamanaka, R.B.; Misharin, A.V.; Perlman, H.; et al. Impaired Clearance of Influenza a Virus in Obese, Leptin Receptor Deficient Mice Is Independent of Leptin Signaling in the Lung Epithelium and Macrophages. PLoS ONE 2014, 9, 1-8. [CrossRef] [PubMed]

200. Smith, A.G.; Sheridan, P.A.; Harp, J.B.; Beck, M.A. Diet-Induced Obese Mice Have Increased Mortality and Altered Immune Responses When Infected with Influenza Virus. J. Nutr. 2007, 137, 1236-1243. [CrossRef] [PubMed] 
201. Holt, P.G. Inhibitory Activity of Unstimulated Alveolar Macrophages on T-Lymphocyte Blastogenic Response. Am. Rev. Respir. Dis. 1978, 118, 791-793. [CrossRef]

202. Krishnan, E.C.; Trost, L.; Aarons, S.; Jewell, W.R. Study of Function and Maturation of Monocytes in Morbidly Obese Individuals. J. Surg. Res. 1982, 33, 89-97. [CrossRef]

203. Yoshimura, A.; Naka, T.; Kubo, M. SOCS Proteins, Cytokine Signalling and Immune Regulation. Nat. Rev. Immunol. 2007, 454-465. [CrossRef]

204. Karlsson, E.A.; Sheridan, P.A.; Beck, M.A. Diet-Induced Obesity Impairs the T Cell Memory Response to Influenza Virus Infection. J. Immunol. 2010, 184, 3127-3133. [CrossRef]

205. Vlotides, G.; Sörensen, A.S.; Kopp, F.; Zitzmann, K.; Cengic, N.; Brand, S.; Zachoval, R.; Auernhammer, C.J. SOCS-1 and SOCS-3 Inhibit IFN- $\alpha$-Induced Expression of the Antiviral Proteins 2,5-OAS and MxA. Biochem. Biophys. Res. Commun. 2004, 320, 1007-1014. [CrossRef]

206. Pauli, E.K.; Schmolke, M.; Wolff, T.; Viemann, D.; Roth, J.; Bode, J.G.; Ludwig, S. Influenza A Virus Inhibits Type I IFN Signaling via NF-KB-Dependent Induction of SOCS-3 Expression. PLoS Pathog. 2008, 4, 1-15. [CrossRef]

207. Liu, S.; Yan, R.; Chen, B.; Pan, Q.; Chen, Y.; Hong, J.; Zhang, L.; Liu, W.; Wang, S.; Chen, J.-L. Influenza Virus-Induced Robust Expression of SOCS3 Contributes to Excessive Production of IL-6. Front. Immunol. 2019, 10, 1843. [CrossRef]

208. Paich, H.A.; Sheridan, P.A.; Handy, J.; Karlsson, E.A.; Schultz-Cherry, S.; Hudgens, M.G.; Noah, T.L.; Weir, S.S.; Beck, M.A. Overweight and Obese Adult Humans Have a Defective Cellular Immune Response to Pandemic H1N1 Influenza a Virus. Obesity 2013, 21, 2377-2386. [CrossRef]

209. Neidich, S.D.; Green, W.D.; Rebeles, J.; Karlsson, E.A.; Schultz-Cherry, S.; Noah, T.L.; Chakladar, S.; Hudgens, M.G.; Weir, S.S.; Beck, M.A. Increased Risk of Influenza among Vaccinated Adults Who Are Obese. Int. J. Obes. 2017, 41, 1324-1330. [CrossRef]

210. Kim, Y.H.; Kim, J.K.; Kim, D.J.; Nam, J.H.; Shim, S.M.; Choi, Y.K.; Lee, C.H.; Poo, H. Diet-Induced Obesity Dramatically Reduces the Efficacy of a 2009 Pandemic H1N1 Vaccine in a Mouse Model. J. Infect. Dis. 2012, 205, 244-251. [CrossRef] [PubMed]

211. Smith, A.G.; Sheridan, P.A.; Tseng, R.J.; Sheridan, J.F.; Beck, M.A. Selective Impairment in Dendritic Cell Function and Altered Antigen-Specific CD8+ T-Cell Responses in Diet-Induced Obese Mice Infected with Influenza Virus. Immunology 2009, 126, 268-279. [CrossRef] [PubMed]

212. Kosaraju, R.; Guesdon, W.; Crouch, M.J.; Teague, H.L.; Sullivan, E.M.; Karlsson, E.A.; Schultz-Cherry, S.; Gowdy, K.; Bridges, L.C.; Reese, L.R.; et al. B Cell Activity Is Impaired in Human and Mouse Obesity and is Responsive to an Essential Fatty Acid upon Murine Influenza Infection. J. Immunol. 2017, 198, 4738-4752. [CrossRef]

213. Zhou, F.; Yu, T.; Du, R.; Fan, G.; Liu, Y.; Liu, Z.; Xiang, J.; Wang, Y.; Song, B.; Gu, X.; et al. Clinical Course and Risk Factors for Mortality of Adult Inpatients with COVID-19 in Wuhan, China: A Retrospective Cohort Study. Lancet 2020, 395, $1054-1062$. [CrossRef]

214. Regina, J.; Papadimitriou-Olivgeris, M.; Burger, R.; Le Pogam, M.-A.; Niemi, T.; Filippidis, P.; Tschopp, J.; Desgranges, F.; Viala, B.; Kampouri, E.; et al. Epidemiology, Risk Factors and Clinical Course of SARS-CoV-2 Infected Patients in a Swiss University Hospital: An Observational Retrospective Study. PLoS ONE 2020, 15, e0240781. [CrossRef] [PubMed]

215. Stefan, N.; Birkenfeld, A.L.; Schulze, M.B. Global Pandemics Interconnected-Obesity, Impaired Metabolic Health and COVID-19. Nat. Rev. Endocrinol. 2021, 1-15. [CrossRef]

216. Frank, R.C.; Mendez, S.R.; Stevenson, E.K.; Guseh, J.S.; Chung, M.; Silverman, M.G. Obesity and the Risk of Intubation or Death in Patients With Coronavirus Disease 2019. Crit. Care Med. 2020, 48, e1097-e1101. [CrossRef]

217. Grippo, F.; Navarra, S.; Orsi, C.; Manno, V.; Grande, E.; Crialesi, R.; Frova, L.; Marchetti, S.; Pappagallo, M.; Simeoni, S.; et al. The Role of COVID-19 in the Death of SARS-CoV-2-Positive Patients: A Study Based on Death Certificates. J. Clin. Med. 2020, 9, 3459. [CrossRef]

218. Sungnak, W.; Huang, N.; Bécavin, C.; Berg, M.; Queen, R.; Litvinukova, M.; Talavera-López, C.; Maatz, H.; Reichart, D.; Sampaziotis, F.; et al. SARS-CoV-2 Entry Factors Are Highly Expressed in Nasal Epithelial Cells Together with Innate Immune Genes. Nat. Med. 2020, 26, 681-687. [CrossRef]

219. Deng, M.; Qi, Y.; Deng, L.; Wang, H.; Xu, Y.; Li, Z.; Meng, Z.; Tang, J.; Dai, Z. Obesity as a Potential Predictor of Disease Severity in Young COVID-19 Patients: A Retrospective Study. Obesity 2020, 28, 1815-1825. [CrossRef]

220. Klang, E.; Kassim, G.; Soffer, S.; Freeman, R.; Levin, M.A.; Reich, D.L. Severe Obesity as an Independent Risk Factor for COVID-19 Mortality in Hospitalized Patients Younger than 50. Obesity 2020, 28, 1595-1599. [CrossRef] [PubMed]

221. Huizinga, G.P.; Singer, B.H.; Singer, K. The Collision of Meta-Inflammation and SARS-CoV-2 Pandemic Infection. Endocrinology 2020, 161, 1-10. [CrossRef] [PubMed]

222. Moore, J.B.; June, C.H. Cytokine Release Syndrome in Severe COVID-19. Science 2020, 368, 473-474. [CrossRef] [PubMed]

223. Krams, I.A.; Luoto, S.; Rantala, M.J.; Jõers, P.; Krama, T. Covid-19: Fat, Obesity, Inflammation, Ethnicity, and Sex Differences. Pathogens 2020, 9, 887. [CrossRef]

224. Battisti, S.; Pedone, C.; Napoli, N.; Russo, E.; Agnoletti, V.; Nigra, S.G.; Dengo, C.; Mughetti, M.; Conte, C.; Pozzilli, P.; et al. Computed Tomography Highlights Increased Visceral Adiposity Associated with Critical Illness in Covid-19. Diabetes Care 2020, e129-e130. [CrossRef] [PubMed]

225. Malavazos, A.E.; Corsi Romanelli, M.M.; Bandera, F.; Iacobellis, G. Targeting the Adipose Tissue in COVID-19. Obesity 2020, 28, 1178-1179. [CrossRef] [PubMed] 
226. Coelho, M.; Oliveira, T.; Fernandes, R. Biochemistry of Adipose Tissue: An Endocrine Organ. Arch. Med. Sci. 2013, 191-200. [CrossRef] [PubMed]

227. Zhang, Y.; Somers, K.R.; Becari, C.; Polonis, K.; Pfeifer, M.A.; Allen, A.M.; Kellogg, T.A.; Covassin, N.; Singh, P. Comparative Expression of Renin-Angiotensin Pathway Proteins in Visceral Versus Subcutaneous Fat. Front. Physiol. 2018, 9, 1370. [CrossRef]

228. Li, W.; Moore, M.J.; Vasllieva, N.; Sui, J.; Wong, S.K.; Berne, M.A.; Somasundaran, M.; Sullivan, J.L.; Luzuriaga, K.; Greeneugh, T.C.; et al. Angiotensin-Converting Enzyme 2 Is a Functional Receptor for the SARS Coronavirus. Nature 2003, 426, 450-454. [CrossRef]

229. Deinhardt-Emmer, S.; Wittschieber, D.; Sanft, J.; Kleemann, S.; Elschner, S.; Haupt, K.; Vau, V.; Häring, C.; Rödel, J.; Henke, A.; et al. Early Postmortem Mapping of SARS-CoV-2 RNA in Patients with COVID-19 and Correlation to Tissue Damage. bioRxiv 2020, 2. [CrossRef]

230. Li, M.Y.; Li, L.; Zhang, Y.; Wang, X.S. Expression of the SARS-CoV-2 Cell Receptor Gene ACE2 in a Wide Variety of Human Tissues. Infect. Dis. Poverty 2020, 9. [CrossRef] [PubMed] 